\title{
The late Pleistocene and Holocene history of Pinus koraiensis (Korean Pine) in the south of the Russian Far East based on palynological data
}

\author{
PAVEL BELYANIN* and NINA BELYANINA \\ Pacific Geographical Institute, Far Eastern Branch, Russian Academy of Sciences, Russia; \\ e-mail: pavelbels@yandex.ru, nibelyanina@yandex.ru
}

Received 21 September 2021; accepted for publication 16 November 2021

\begin{abstract}
This paper reviews the distribution of Pinus koraiensis in the south of the Russian Far East in the past based on palynological and chronological data. The aim is to determine the chronological timing of the spatial migration of Pinus koraiensis and to correlate it with climate fluctuations explaining the changes of the geographical range of Pinus koraiensis in the south of the Russian Far East during the Marine Isotope Stages MIS 5 (127 000-71 000 BP), MIS 3 (57 000 BP - 28000 cal BP), MIS 2 (28 000-11 700 cal BP), and MIS 1 (11 700 cal BP - to present). The consideration of the obtained pollen fossil data suggests that the range of Pinus koraiensis was in the south of the Russian Far East during MIS 5, as it was proved based on significant pollen grain percentage in the sediments of this age. Pinus koraiensis was widespread along with Pinus densiflora, Quercus, Ulmus, Juglans, Carpinus, and Phellodendron. During MIS 3, Pinus koraiensis was a component of birch-fir and birch-broadleaved forests. In MIS 2, Pinus koraiensis disappeared from the vegetation of this region. In the early Holocene, Pinus koraiensis expanded its range northward and again appeared in the vegetation of the south of the Russian Far East. Soon enough, it became one of the leading components in spruce-fir forests with Quercus and Ulmus. The increase in its proportion in the vegetation in the Holocene coincided mostly with the periods of warming climate from 11700 to 11500 cal BP, from 10100 to 9300 cal BP, from 8800 to 5300 cal BP, from 4700 to $3500 \mathrm{cal} \mathrm{BP}$, and from 2600 to $1800 \mathrm{cal} \mathrm{BP}$. In the present case, the most diverse vegetation with Pinus koraiensis was typical of the Holocene optimum of the south of the Russian Far East from 8800 to 5300 cal BP.
\end{abstract}

KEYWORDS: pollen, Pinus koraiensis, spatial and temporal migration of plants, south of the Russian Far East, late Pleistocene, Holocene

\section{INTRODUCTION}

Climatic changes during the late Pleistocene and the Holocene resulted in large-scale plant migrations (Birks, 1986; Lang, 1994). A notable migration is that of Pinus koraiensis (Korean Pine), one of the main forest-forming species in the south of the Russian Far East, the region where primary forests have been preserved (Krestov, 2003).

The south of the Russian Far East is located in the contact zone of the Amur, Manchurian and North China floristic provinces, where

\footnotetext{
Corresponding author
}

plants characteristic of boreal and warm-temperate zones are common (Komarov, 1949). Therefore, this is a key area for studies on plant migration due to shifting of their distribution ranges caused by fluctuations of climate and environmental changes during the late Pleistocene and the Holocene.

Though the evolution of vegetation in the south of the Russian Far East during the late Pleistocene and the Holocene has been investigated in considerable detail (Alekseyev and Golubeva, 1980; Golubeva and Karaulova, 1983; Korotky, 2002; Pavlyutkin 
and Belyanina, 2002; Mikishin et al., 2008; Razjigaeva et al., 2016; Anderson et al., 2017; Belyanin and Belyanina, 2018), the spatial and temporal migration of plants in the region have not been sufficiently understood so far.

The above is true in particular for the spatial dynamics of Pinus koraiensis in MIS 5 (127 000$71000 \mathrm{BP}$, MIS $3(57000 \mathrm{BP}-28000 \mathrm{cal} \mathrm{BP})$, MIS 2 (28 000-11700 cal BP), and MIS 1 (11 $700 \mathrm{cal} \mathrm{BP}$ - to present). Most likely, it may be attributed to some gaps in the pollen records. Slight changes in the ranges of plants resulting from low-amplitude and short-term climatic fluctuations are difficult to record. Besides, the sediments of the late Pleistocene and early Holocene lie deep from the Earth's surface. All the above interferes considerably with reconstructing paleo-environments and forecasting the evolution of the vegetation in the south of the Russian Far East (Zhang et al., 2014).

Previously, palaeobotanical data were obtained that allowed the reconstruction of the history of Pinus koraiensis in the south of the Russian Far East during MIS 1 (11 $700 \mathrm{cal}$ BP - to present) (Belyanin and Belyanina, 2019). However, epochs MIS 5 (127 000-71000 BP), MIS 3 (57 $000 \mathrm{BP}-28000 \mathrm{cal} \mathrm{BP}$ ), and MIS 2 (28 000-11700 cal BP) remained outside the field of studies. Recently, palynological data have been obtained and analysed contributing to the more detailed reconstruction of the history of Pinus koraiensis in the south of the Russian Far East during the epochs mentioned above.

The present work aims to reconstruct the distribution of Pinus koraiensis in the south of the Russian Far East in respect of vegetation history, a geographical range, dispersal, and migration during MIS 5 (127 000-71 000 BP),
MIS $3(57000 \mathrm{BP}-28000$ cal BP), MIS 2 (28 000-11 $700 \mathrm{cal} \mathrm{BP}$ ), and MIS 1 (11 $700 \mathrm{cal}$ $\mathrm{BP}$ - to present) to gain better understanding of its past distribution, and also to predict the future distribution of Pinus koraiensis, taking into account the changing climate and environment.

\section{ENVIRONMENTAL SETTING}

The climate of the south of the Russian Far East is mainly controlled by the East Asian monsoon (Drozdov et al., 1989). Continental climate influence increases from the coast to inland. During the winter season, dry and cold winds blow towards the southeast from the Asian continent. In the summer season warm and humid winds come from the ocean. Mean temperatures in July and in January are ranging from $18^{\circ} \mathrm{C}$ to $20^{\circ} \mathrm{C}$, and from $-12^{\circ} \mathrm{C}$ to $-21^{\circ} \mathrm{C}$, respectively.

The average annual precipitation is between 550 and $920 \mathrm{~mm}$ and the most of it falls in summer. The relief of the eastern part of the south of the Russian Far East is mountainous, with average heights of the hills up to $600 \mathrm{~m}$. The lowland sites are located in the coastal zone of the Sea of Japan, and the Pre-Khanka Plain, and the Ussuri River Valley.

\section{THE GEOGRAPHICAL DISTRIBUTION AND ECOLOGY OF PINUS KORAIENSIS}

The occurrence of Pinus koraiensis mostly depends on the climate (Solovyev, 1958). The leading factors, which determine the

Table 1. The extreme and optimum values of the most important climatic parameters, which determine the range of Pinus koraiensis in the south of the Russian Far East (Kolesnikov, 1954)

\begin{tabular}{|c|c|c|c|}
\hline \multirow{2}{*}{ Parameter of climate } & \multicolumn{3}{|c|}{ Physical characteristics } \\
\hline & minimum & maximum & optimum \\
\hline Mean annual temperature $\left[{ }^{\circ} \mathrm{C}\right]$ & 0 & +6 & - \\
\hline Extreme values of daily temperature $\left[{ }^{\circ} \mathrm{C}\right]$ & -50 & +40 & - \\
\hline Number of months in a year with mean temperature $0^{\circ} \mathrm{C}$ & 6 & 8 & 7 \\
\hline Growing period [days] & 150 & 200 & $170-180$ \\
\hline Degree day temperatures $\left[{ }^{\circ} \mathrm{C}\right]$ & 100 & 170 & $120-150$ \\
\hline Sum of the temperatures in the vegetative period & 2600 & $>3200$ & - \\
\hline Mean annual precipitation $[\mathrm{mm}]$ & 500 & 1000 & $600-700$ \\
\hline Extreme values of mean annual rainfall in individual years [mm] & 320 & $>1200$ & - \\
\hline Mean annual relative air humidity as recorded at 13 p.m. [\%] & 60 & 72 & $<70$ \\
\hline $\begin{array}{l}\text { Mean relative air humidity as recorded at } 13 \text { p.m. } \\
\text { of the most rainy month (July or August) [\%] }\end{array}$ & 68 & 91 & 75 \\
\hline $\begin{array}{l}\text { Mean relative air humidity as recorded at } 13 \text { p.m. } \\
\text { of the driest month in the growing period (April or May) [\%] }\end{array}$ & 41 & 45 & - \\
\hline
\end{tabular}




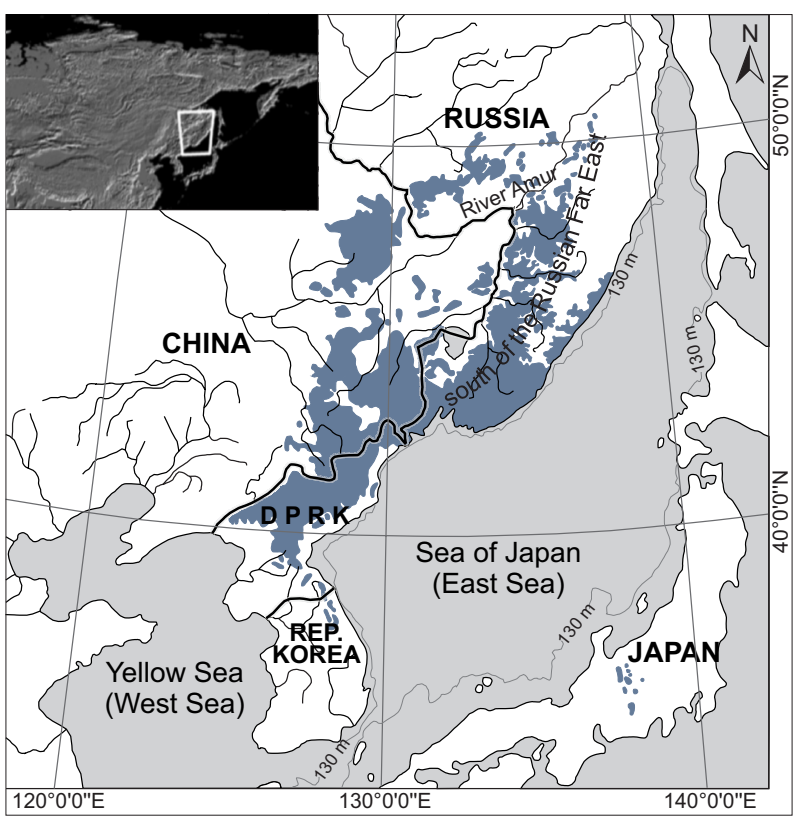

Fig. 1. The geographical distribution of Pinus koraiensis (Critchfield and Little, 1966; Krestov et al., 2006)

composition and structure of a mixed forest with Pinus koraiensis are as follows: the maximum temperature of the warmest month, the mean temperature of the warmest quarter of a year and the total precipitation of the wettest month (Zhang et al., 2014). The extreme and optimum values of the most important climatic parameters, which determine the range of Pinus koraiensis in the south of the Russian Far East are given in Table 1 (Kolesnikov, 1954).

Pinus koraiensis is a typical element of the vegetation in the East Asia mountain ecosystem of the Sikhote-Alin, Wanda, and Manchurian-Korean Mountains, Changbai Plateau, and the Maliy Khingan Ridge (Kolesnikov, 1954, 1956; Nakamura and Krestov, 2005). On the Islands of Japan, it is found in some locations in the Central and Southern Japanese Alps (Honshu Isl.), as well as on Shikoku Island (Ohwi, 1965) (Fig. 1). However, the most favourable climatic conditions for its growth exist between latitudes $41^{\circ} \mathrm{N}$ and $49^{\circ} \mathrm{N}$ in North Korea and northeastern China (Kolesnikov, 1954; Urusov, 1999).

In the south of the Russian Far East, the greatest part of the Pinus koraiensis range covers the Amur River drainage basin and a smaller part does the coast of the Sea of Japan. In this range Pinus koraiensis is mostly confined to the altitudes between 200 and 900 m a.s.l.

\section{IDENTIFICATION OF THE PINUS KORAIENSIS POLLEN}

In the modern vegetation of the south of the Russian Far East, genus Pinus is represented by two subgenera - Pinus subgen. Haploxylon (Strobus) and Pinus subgen. Diploxylon. Pinus subgen. Haploxylon includes two species Pinus koraiensis and Pinus pumila, and Pinus subgen. Diploxylon is represented by one species - Pinus densiflora.

Fossil pollen of these species is found in the Pleistocene and Holocene sediments in the south of the Russian Far East. To distinguish between the fossil pollen of Pinus koraiensis, Pinus pumila, and Pinus densiflora, several pollen grains were selected from each unevenaged palynological assemblage with a similar structure of palynospectra. After acetolysis, they were placed in glycerol jelly. Using an Axio Scope.A1 optical microscope and an AxioCam ICc1 camera (Carl Zeiss), five parameters of pollen grains were measured: $\sum$ (pollen length with sacci), A (pollen body length), B (pollen width), C (length of saccus), D (width of saccus) in an equatorial view (Fig. 2).

Based on the obtained values, the biometric characteristics $-\beta, \delta, \gamma$ were calculated and the angles between the axes of symmetry of the air sacs of the pollen grains of Pinus koraiensis, Pinus pumila, and Pinus densiflora were determined. The biometric parameters obtained using the method of Monoszon-Smolina (1949) were compared with the biometric characteristics of recent pollen grains (Tab. 2). This made the identification of the pollen of these species possible. A total of 58 pollen grains have been analysed.

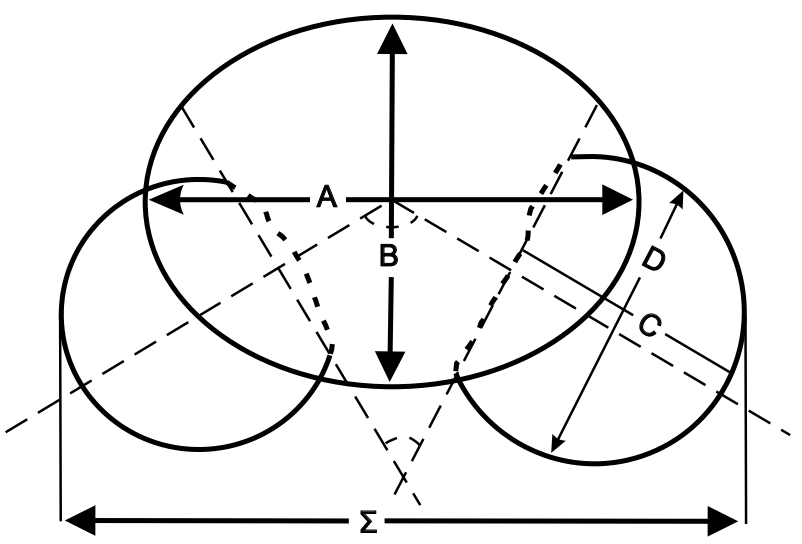

Fig. 2. Schematic representation of Pinus pollen grain indicating the positions of five parameters measured. $\Sigma$ - pollen length with sacci, A - pollen body length, B - pollen width, $\mathrm{C}$ - length of saccus, D - width of saccus 
Table 2. Distinctive biometric characteristics of the pollen of Pinus koraiensis, P. pumila, and P. densiflora (MonoszonSmolina, 1949)

\begin{tabular}{|c|c|c|c|c|c|}
\hline Species & $\begin{array}{l}\text { Total pollen } \\
\text { grain size } \Sigma, \mu \mathrm{m}\end{array}$ & $\begin{array}{l}\text { Index } \\
\beta=\mathrm{A} / \mathrm{B}\end{array}$ & $\begin{array}{c}\text { Index } \\
\delta=\mathrm{B} / \mathrm{D}\end{array}$ & $\begin{array}{c}\text { Index } \\
\gamma=\mathrm{A} / \mathrm{D}\end{array}$ & $\begin{array}{l}\text { The angle between } \\
\text { the axes of symmetry } \\
\text { of the air sacs }\end{array}$ \\
\hline $\begin{array}{l}\text { Pinus } \\
\text { koraiensis }\end{array}$ & $\begin{array}{c}69.0-90.0 \\
\text { (on average } 80.6 \text { ) }\end{array}$ & $\begin{array}{c}1.03-1.44 \\
\text { (dominated } 1.2-1.4)\end{array}$ & $\begin{array}{c}0.8-1.5 \\
\text { (dominated } 1.15-1.35)\end{array}$ & $\begin{array}{c}1.2-1.9 \\
\text { (dominated 1.5-1.8) }\end{array}$ & $\begin{array}{c}104^{\circ}-124^{\circ} \\
\left(\text { dominated }<120^{\circ}\right)\end{array}$ \\
\hline $\begin{array}{l}\text { Pinus } \\
\text { pumila }\end{array}$ & $\begin{array}{c}72.0-99.0 \\
\text { (on average } 86.2 \text { ) }\end{array}$ & $\begin{array}{c}1.13-1.33 \\
\text { (dominated 1.2-1.3) }\end{array}$ & $\begin{array}{c}0.9-1.29 \\
\text { (dominated } 1.05-1.2)\end{array}$ & $\begin{array}{c}1.1-1.62 \\
\text { (dominated } 1.2-1.5)\end{array}$ & $\begin{array}{c}127^{\circ}-149^{\circ} \\
\left(\text { dominated }>135^{\circ}\right)\end{array}$ \\
\hline $\begin{array}{l}\text { Pinus } \\
\text { densiflora }\end{array}$ & $\begin{array}{c}60-78 \\
\text { (on average 69.9) }\end{array}$ & $\begin{array}{c}1.2-1.5 \\
\text { (dominated } 1.25-1.35)\end{array}$ & $\begin{array}{c}1.11-1.63 \\
\text { (dominated } 1.25-1.5)\end{array}$ & $\begin{array}{c}1.53-2.13 \\
\text { (dominated } 1.6-1.9)\end{array}$ & $\begin{array}{c}135^{\circ}-160^{\circ} \\
\left(\text { dominated }>140^{\circ}\right)\end{array}$ \\
\hline
\end{tabular}

When identifying these species, the morphological features of pollen and sculptural patterns of pollen grains were also taken into account. The air sacs of Pinus koraiensis and Pinus pumila are spheroidal. Their upper part is located 1/3 higher than the middle line of the body of the pollen grain. The air sacs of Pinus koraiensis are large and distinct, with closed walls (Monoszon-Smolina, 1949). Their outlines are continuous in polar projection (Song et al., 2012). The diameter of the air sacs of Pinus koraiensis on the ventral side is almost the same as that of the body. Their structure is a uniform coarse mesh, through which a finer mesh appears. Exine has a fine, almost punctual structure, more distinct on the upper side of the body. The height of the exine above the line of sac attachment in Pinus koraiensis reaches a greater value than in Pinus pumila (Litvintseva, 1975; Monoszon-Smolina, 1949).

An important morphological feature of Pinus pumila pollen is large bumps $(3.0-4.0 \mu \mathrm{m})$ at the base of the sacks, while Pinus koraiensis has simple waviness. The mesh structure of the pollen sacs of Pinus pumila is formed by the alternation of large and small cells. The length of the pollen sac is the same for one and other species, but its width in Pinus koraiensis is greater (Monoszon-Smolina, 1949; Litvintseva, 1975).

A distinctive feature of the pollen of another representative of the genus Pinus, the species of Pinus densiflora, is the location and the shape of the air sacs. The air sacs are located below the midline of the body of the pollen grain, which has a uniformly thickened exine. When considering the pollen grain in the lateral position, the air sacs have the form of three overlapping circles. On the ventral side, the boundaries of attachment of air sacs are sharply drawn together. The angle between the axes of their symmetry varies between $135^{\circ}$ and $160^{\circ}$ (with the predominance of an angle $>140^{\circ}$ ), which is much more than that of Pinus pumila and Pinus koraiensis. The exine of the body is somewhat thicker on the dorsal side. It is represented by a small pattern evenly covering the entire surface (Monoszon-Smolina, 1949; Litvintseva, 1975). The air sacs of Pinus densiflora are discontinuous in polar projection with the outline of the body, so that the pollen grains appear to be composed of three separate oval parts (Song et al., 2012). Pollen of Pinus densiflora is characterised by a lighter color and transparency (Monoszon-Smolina, 1949).

\section{MATERIALS AND METHODS}

To reconstruct the late Pleistocene and Holocene history of Pinus koraiensis in the south of the Russian Far East, previously published paleobotanical materials (Korotky et al., 1980; Pavlyutkin et al., 1984; Korotky, 2002; Pavlyutkin and Belyanina, 2002; Bazarova et al., 2008; Mikishin et al., 2008; Anderson et al., 2017; Belyanin and Belyanina, 2018, 2020; Belyanin et al., 2018, 2019) were combined with new laboratory data on Pinus koraiensis fossil pollen data and chronological data on MIS 5 (127 000-71 000 BP), MIS 3 (57000 BP - 28000 cal BP), MIS 2 (28 000$11700 \mathrm{cal} \mathrm{BP})$ and MIS 1 (11 $700 \mathrm{cal} \mathrm{BP}$ - to present). A significant part of Pinus koraiensis fossil pollen and chronological data was obtained, collected, and analysed from the NFE, CFE, and SFE ecological zones in the region (Tab. 3). Since the age of MIS 4 (71 000$57000 \mathrm{BP}$ ) sediments is beyond radiocarbon dating and the pollen records of this age are absent in the south of the Russian Far East, we cannot reconstruct the history of Pinus koraiensis during MIS 4.

\section{COLLECTION, PREPARATION OF THE SEDIMENT SAMPLES AND PALYNOLOGICAL ANALYSIS}

New Pinus koraiensis fossil pollen data and chronological data were obtained from cross-sections 9119 , 6 159, 1 706-1 and 6 022. Sediments samples were taken at intervals of $5-10 \mathrm{~cm}$. Fossil pollen particles were extracted from the sediments using standard methods, which included treatment with $10 \% \mathrm{KOH}$, separation of minerals with a solution of KJ and CdJ2 $\left(2.2 \mathrm{~g} / \mathrm{cm}^{3}\right)$, after which the samples were acetolysed and mounted in glycerol jelly (Pokrovskaya, 1950). Pollen and spores in glycerin jelly were identified, 
Table 3. Geographic coordinates of the cross-sections and cores, their, elevation, and source of publication

\begin{tabular}{|c|c|c|c|c|c|}
\hline Cores and Cross-sections & Subregion & $\begin{array}{l}\text { No. on } \\
\text { Fig. } 3 \\
\end{array}$ & Location & Altitude [m a.s.l.] & $\begin{array}{c}\text { Reference to publication } \\
\text { source }\end{array}$ \\
\hline Core 33 & $\mathrm{SFE}$ & 1 & $\begin{array}{r}43^{\circ} 31^{\prime} 43.43^{\prime \prime} \mathrm{N} \\
131^{\circ} 52^{\prime} 40.55^{\prime \prime} \mathrm{E}\end{array}$ & 5 & $\begin{array}{l}\text { Pavlyutkin and Belyanina, } \\
2002\end{array}$ \\
\hline Core 11 & $\mathrm{SFE}$ & 2 & $\begin{array}{r}42^{\circ} 50^{\prime} 45.08^{\prime \prime} \mathrm{N} \\
133^{\circ} 00^{\prime} 11.04^{\prime \prime} \mathrm{E}\end{array}$ & 2 & $\begin{array}{l}\text { Pavlyutkin and Belyanina, } \\
2002\end{array}$ \\
\hline Core 10 & NFE & 3 & $\begin{array}{r}48^{\circ} 14^{\prime} 33.11^{\prime \prime} \mathrm{N} \\
138^{\circ} 29^{\prime} 44.45^{\prime \prime} \mathrm{E}\end{array}$ & 1320 & Korotky, 2002 \\
\hline Cross-section 6204 & NFE & 4 & $\begin{array}{r}46^{\circ} 28^{\prime} 38.55^{\prime \prime} \mathrm{N} \\
134^{\circ} 12^{\prime} 07.24^{\prime \prime} \mathrm{E}\end{array}$ & 58 & Belyanin and Belyanina, 2018 \\
\hline Core Lake Karasie & $\mathrm{SFE}$ & 5 & $\begin{array}{r}42^{\circ} 39^{\prime} 28.26^{\prime \prime} \mathrm{N} \\
130^{\circ} 58^{\prime} 30.29^{\prime \prime} \mathrm{E}\end{array}$ & $\begin{array}{c}0.2 \\
\text { (water depth } 1.5 \mathrm{~m} \text { ) }\end{array}$ & Anderson et al., 2017 \\
\hline Cross-section Tikhangoy Bay & $\mathrm{SFE}$ & 6 & $\begin{array}{r}43^{\circ} 50^{\prime} 28.49^{\prime \prime} \mathrm{N} \\
132^{\circ} 47^{\prime} 04.12^{\prime \prime} \mathrm{E} \\
\end{array}$ & 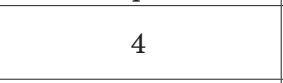 & Korotky, 2002 \\
\hline Cross-section Ovrazhnyii-2 & $\mathrm{CFE}$ & 7 & $\begin{array}{r}43^{\circ} 15^{\prime} 45.29^{\prime \prime} \mathrm{N} \\
138^{\circ} 33^{\prime} 08.58^{\prime \prime} \mathrm{E} \\
\end{array}$ & 20 & Korotky, 2002 \\
\hline Cross-section Akulinin & NFE & 8 & $\begin{array}{r}47^{\circ} 03^{\prime} 51.57^{\prime \prime} \mathrm{N} \\
134^{\circ} 34^{\prime} 28.01^{\prime \prime} \mathrm{E}\end{array}$ & 10 & Korotky, 2002 \\
\hline Cross-section 6205 & NFE & 9 & $\begin{array}{r}46^{\circ} 29^{\prime} 38.57^{\prime \prime} \mathrm{N} \\
134^{\circ} 29^{\prime} 07.29^{\prime \prime} \mathrm{E} \\
\end{array}$ & 64 & Belyanin and Belyanina, 2018 \\
\hline Cross-section 6276 & $\mathrm{CFE}$ & 10 & $\begin{array}{r}44^{\circ} 57^{\prime} 30.02^{\prime \prime} \mathrm{N} \\
133^{\circ} 08^{\prime} 03.08^{\prime \prime} \mathrm{E}\end{array}$ & 70 & Belyanin and Belyanina, 2020 \\
\hline Core 579 & $\mathrm{CFE}$ & 11 & $\begin{array}{r}44^{\circ} 52^{\prime} 44.02^{\prime \prime} \mathrm{N} \\
132^{\circ} 39^{\prime} 48.24^{\prime \prime} \mathrm{E}\end{array}$ & $\begin{array}{c}67 \text { (water depth } \\
1.5 \mathrm{~m} \text { ) }\end{array}$ & Belyanin and Belyanina, 2012 \\
\hline Cross-section c & $\mathrm{SFE}$ & 12 & $\begin{array}{r}42^{\circ} 57^{\prime} 06.46^{\prime \prime} \mathrm{N} \\
133^{\circ} 10^{\prime} 28.44^{\prime \prime} \mathrm{E}\end{array}$ & (2) & Korotky, 2002 \\
\hline Core 508 & $\mathrm{CFE}$ & 13 & $\begin{array}{r}44^{\circ} 51^{\prime} 16.08^{\prime \prime} \mathrm{N} \\
133^{\circ} 02^{\prime} 47.23^{\prime \prime} \mathrm{E}\end{array}$ & 78 & Belyanin and Belyanina, 2020 \\
\hline Cross-section 9119 & $\mathrm{SFE}$ & 14 & $\begin{array}{r}44^{\circ} 20^{\prime} 07.29^{\prime \prime} \mathrm{N} \\
132^{\circ} 36^{\prime} 05.49^{\prime \prime} \mathrm{E} \\
\end{array}$ & 22 & unpublished \\
\hline Core 9 & $\mathrm{SFE}$ & 15 & $\begin{array}{r}42^{\circ} 52^{\prime} 06.31^{\prime \prime} \mathrm{N} \\
133^{\circ} 00^{\prime} 15.02^{\prime \prime} \mathrm{E}\end{array}$ & 2 & $\begin{array}{l}\text { Pavlyutkin and Belyanina, } \\
2002\end{array}$ \\
\hline Cross-section 1438 & $\mathrm{CFE}$ & 16 & $\begin{array}{r}44^{\circ} 20^{\prime} 07.09^{\prime \prime} \mathrm{N} \\
132^{\circ} 36^{\prime} 05.18^{\prime \prime} \mathrm{E} \\
\end{array}$ & 75 & Korotky et al., 1980 \\
\hline Core 272 & $\mathrm{SFE}$ & 17 & $\begin{array}{r}42^{\circ} 42^{\prime} 02.25^{\prime \prime} \mathrm{N} \\
130^{\circ} 56^{\prime} 31.08^{\prime \prime} \mathrm{E} \\
\end{array}$ & 5 & Mikishin et al., 2008 \\
\hline $\begin{array}{l}\text { Cross-section Bolotisty } \\
\text { Stream }\end{array}$ & NFE & 18 & $\begin{array}{r}48^{\circ} 53^{\prime} 59.02^{\prime \prime} \mathrm{N} \\
137^{\circ} 15^{\prime} 22.15^{\prime \prime} \mathrm{E} \\
\end{array}$ & 512 & Belyanin et al., 2018 \\
\hline Cross-section 4005 & $\mathrm{SFE}$ & 19 & $\begin{array}{r}43^{\circ} 51^{\prime} 32.30^{\prime \prime} \mathrm{N} \\
131^{\circ} 27^{\prime} 55.12^{\prime \prime} \mathrm{E}\end{array}$ & 5 & $\begin{array}{l}\text { Pavlyutkin and Belyanina, } \\
2002\end{array}$ \\
\hline Cross-section 6010 & NFE & 20 & $\begin{array}{r}46^{\circ} 39^{\prime} 01.19^{\prime \prime} \mathrm{N} \\
134^{\circ} 24^{\prime} 17.06^{\prime \prime} \mathrm{E} \\
\end{array}$ & 63 & Belyanin and Belyanina, 2018 \\
\hline Cross-section Kazachka River & $\mathrm{SFE}$ & 21 & $\begin{array}{r}43^{\circ} 51^{\prime} 32.13^{\prime \prime} \mathrm{N} \\
131^{\circ} 27^{\prime} 55.62^{\prime \prime} \mathrm{E} \\
\end{array}$ & 82 & Pavlyutkin et al., 1984 \\
\hline Cross-section 6159 & $\mathrm{CFE}$ & 22 & $\begin{array}{r}44^{\circ} 49^{\prime} 17.34^{\prime \prime} \mathrm{N} \\
133^{\circ} 03^{\prime} 54.00^{\prime \prime} \mathrm{E}\end{array}$ & 75 & unpublished \\
\hline Cross-section 6056 & $\mathrm{NFE}$ & 23 & $\begin{array}{r}46^{\circ} 33^{\prime} 33.24^{\prime \prime} \mathrm{N} \\
134^{\circ} 10^{\prime} 43.71^{\prime \prime} \mathrm{E}\end{array}$ & 63 & Belyanin and Belyanina, 2018 \\
\hline Core Lake Utinoye & $\mathrm{SFE}$ & 24 & $\begin{array}{r}43^{\circ} 22^{\prime} 34.07^{\prime \prime} \mathrm{N} \\
131^{\circ} 45^{\prime} 17.62^{\prime \prime} \mathrm{E} \\
\end{array}$ & $\begin{array}{c}0.3 \\
\text { (water depth } 3.5 \mathrm{~m} \text { ) }\end{array}$ & Anderson et al., 2017 \\
\hline Cross-section 1 706-1 & $\mathrm{SFE}$ & 25 & $\begin{array}{r}43^{\circ} 25^{\prime} 13.99^{\prime \prime} \mathrm{N} \\
132^{\circ} 11^{\prime} 34.56^{\prime \prime} \mathrm{E} \\
\end{array}$ & 1.8 & unpublished \\
\hline Cross-section 9 031a & $\mathrm{SFE}$ & 26 & $\begin{array}{r}42^{\circ} 50^{\prime} 45.02^{\prime \prime} \mathrm{N} \\
133^{\circ} 00^{\prime} 11.01^{\prime \prime} \mathrm{E}\end{array}$ & 2 & $\begin{array}{l}\text { Pavlyutkin and Belyanina, } \\
2002\end{array}$ \\
\hline Cross-section 1504 & NFE & 27 & $\begin{array}{r}47^{\circ} 02^{\prime} 05.09^{\prime \prime} \mathrm{N} \\
138^{\circ} 35^{\prime} 44.03^{\prime \prime} \mathrm{E}\end{array}$ & 6 & Korotky, 2002 \\
\hline Cross-section 1 508-1 & $\mathrm{SFE}$ & 28 & $\begin{array}{r}42^{\circ} 22^{\prime} 49.05^{\prime \prime} \mathrm{N} \\
130^{\circ} 45^{\prime} 17.00^{\prime \prime} \mathrm{E}\end{array}$ & 2.8 & Belyanin et al., 2018 \\
\hline Cross-section 6022 & NFE & 29 & $\begin{array}{r}46^{\circ} 37^{\prime} 82.89^{\prime \prime} \mathrm{N} \\
134^{\circ} 29^{\prime} 48.24^{\prime \prime} \mathrm{E} \\
\end{array}$ & 58 & unpublished \\
\hline Cross-section Kiya & NFE & 30 & $\begin{array}{l}47^{\circ} 55^{\prime} 232.59^{\prime \prime} \mathrm{N} \\
134^{\circ} 55^{\prime} 23.54^{\prime \prime} \mathrm{E}\end{array}$ & 53 & Bazarova et al., 2008 \\
\hline
\end{tabular}


photographed and counted using an optical microscope Axio Scope.A1 and camera AxioCam ICc1(Carl Zeiss). At least 250 pollen grains of arboreal, dwarf shrubs, and herb were counted in each sample. Identifications of pollen grains were made with the aid of pollen atlases (Nakamura, 1980; Pokrovskaya, 1950). Proportion of each pollen taxon was calculated in percent of the pollen sum arboreal taxa, dwarf shrubs and herbs. Latin names are given according to Plants of the World Online (POWO, 2019). The results of the palynological analysis are plotted in diagrams using the software Tilia v. 2-0-41 (Grimm, 2004).

\section{DATING}

The chronology of the Pinus koraiensis pollen records is based on radiocarbon dates. Four samples of wood, plant detritus, and buried soil were dated using the radiocarbon method in the Laboratory of Geochronology, St Petersburg State University (Kh.A. Arslanov and F.B. Maksimov) and in the Institute of Geological Sciences of National Academy of Sciences of Ukraine (N.N. Kovalyukh). Radiocarbon ages within the sensitivity of the radiocarbon method were calibrated using OxCal 4.4 with the «IntCal 20» calibration curve (Bronk Ramsey, 2017; Reimer et al., 2020) (Tab. 4).

Palaeobotanical data were correlated using the General Stratigraphic Scale of the Quaternary System (Borisov, 2009). The age division of the Pleistocene is given in accordance with Marine Isotope Stages (MIS) (Bassinot et al., 1994). The subdivision of the Holocene was related to the stratigraphic scheme of the Quaternary suggested by the Sub-Commission on Quaternary Stratigraphy and by the INTIMATE Working Group (Walker et al., 2012). Small climatic changes are identified based on the regional stratigraphic scale for the Russian Far East (Korotky et al., 1980; Korotky, 2002).

\section{MAPPING}

A map of Pinus koraiensis fossil pollen distribution in MIS 5, MIS 3, MIS 2, and MIS 1 (see Fig. 1) was produced by plotting the locations where Pinus koraiensis fossil pollen was reported. Geographical locations of the pollen data collection sites are divided into three groups based on their geographical positions in three subregions: north (NFE), central (CFE), and south (SFE). ArcGIS version 10.5 and Corel Draw version 20 were employed to produce the past distribution map of Pinus koraiensis.

\section{RESULTS}

\section{PINUS KORAIENSIS POLLEN IN THE} SEDIMENTS OF MIS 5 (127 000-71 000 BP)

According to the published palaeobotanical data on MIS 5 by Pavlyutkin and Belyanina (2002), Pinus koraiensis pollen fossils are found in the sediments of the Partizanskaya River floodplain, in core 11 , in the SFE subregion (Fig. 3) $(107000 \pm 4500 \mathrm{BP}$ and 85500 $\pm 2000 \mathrm{BP})$ and in the lower reaches of the
Razdolnaya River, SFE, in core 33 SFE (80 600 $\pm 2900 \mathrm{BP}$ ), in the south of the Russian Far East. In the pollen assemblages the pollen of the broadleaved species such as Quercus, Ulmus, Carpinus, Tilia, and Syringa dominates. This indicates that Pinus koraiensis grew in the forests with a diverse composition (Fig. 4).

\section{PINUS KORAIENSIS POLLEN IN THE}

SEDIMENTS OF MIS 3 (57000 BP - 28000 cal BP)

According to palaebotanical reports from the south of the Russian Far East related to MIS 3, Pinus koraiensis fossil pollen was found at the Kontrovod River Basin in cross-section 6 204, NFE (>54 000 BP, 40 329-39 199 cal BP and 31 977-31 273 cal BP) (Belyanin and Belyanina, 2018), at the Opasnaya River Valley in core 10 and in cross-section Akulinin, NFE (46 100-45 005 cal BP and 45 476-42 221 cal BP, respectively) (Korotky, 2002), at the Neprimetnaya Bay in cross-section Ovrazhnyii-2, CFE (35 317-33 918 cal BP) (Korotky, 2002), at the Opasnaya River Valley in crosssection Akulinin, NFE (34 892-32 771 cal BP) (Korotky, 2002) and in the cross-section of the Tikhangoy Bay, SFE (35 464-28 587 cal BP) (Korotky, 2002). A large proportion of Pinus koraiensis fossil pollen with $12 \%$ in a pollen assemblage was obtained from the bottom sediments of Lake Karasie, SFE (41 014-40 563 cal BP (Anderson et al., 2017).

\section{PINUS KORAIENSIS POLLEN IN THE SEDIMENTS OF MIS 2 (28 000-11 700 cal BP)}

During MIS 2, Pinus koraiensis fossil has not been found at the lower reaches of the Kontrovod River in cross-section 6 205, NFE (22 368-21 292 cal BP, 18 269-17 849 cal BP and 14 867-14 039 cal BP) (Belyanin and Belyanina, 2018), near Novorusanovka Village, in cross-section 6 276, CFE (22 974-22 105 cal $\mathrm{BP})$, at the Opasnaya River Valley in crosssection Akulinin, NFE (27 262-26 918 cal BP) (Korotky, 2002) and on the Pre-Khanka Plain, in core 579, CFE (22 169-21 021 cal BP (Belyanin and Belyanina, 2012) (Fig. 5). Nevertheless, the rare Pinus koraiensis fossil pollen has been recorded in the south of the Russian Far East at the lower reaches of the Partizanskaya River, in cross-section Unashi, SFE (21 403-20 670 cal BP and 13 601-13 156 cal BP) (Korotky, 2002) and in the core of Lake Karasie, SFE (20 85620558 cal BP) (Anderson et al., 2017). 
Table 4. Radiocarbon and Uranium series dates (Korotky et al., 1980; Pavlyutkin et al., 1984; Korotky, 2002; Pavlyutkin and Belyanina, 2002; Bazarova et al., 2008; Mikishin et al., 2008; Anderson et al., 2017; Belyanin and Belyanina, 2018, 2020; Belyanin et al., 2018, 2019)

\begin{tabular}{|c|c|c|c|c|c|c|}
\hline Cores and Cross-sections & $\begin{array}{l}\text { No on } \\
\text { Fig. } 3\end{array}$ & $\begin{array}{l}\text { Depth } \\
\text { [m] }\end{array}$ & $\begin{array}{l}\text { Dated } \\
\text { material }\end{array}$ & $\begin{array}{l}\text { Laboratory } \\
\text { number }\end{array}$ & ${ }^{14} \mathrm{C}$ age, $\mathrm{BP}$ & $\begin{array}{c}\text { Calibrated age range, } \\
\text { cal BP (probability) }\end{array}$ \\
\hline Core 11 & 1 & 16.5 & quartz & $\mathrm{K}-173$ & $107000 \pm 4500$ & - \\
\hline Core 11 & 1 & 14.9 & quartz & $\mathrm{K}-172$ & $85500 \pm 2000$ & - \\
\hline Core 33 & 2 & 9.1 & quartz & $\mathrm{K}-171$ & $80600 \pm 2900$ & - \\
\hline Cross-section 6204 & 4 & 12.6 & wood & $\mathrm{Ki}-3371$ & $>54000$ & - \\
\hline Core 10 & 3 & 4.2 & peat & $\mathrm{Ki}-2403$ & $46200 \pm 280$ & $46100-45005(95.4 \%)$ \\
\hline Cross-section Akulinin & 8 & $5.1-5.0$ & wood & $\mathrm{Ki}-1849$ & $40040 \pm 1200$ & $45 \quad 476-42221(95.4 \%)$ \\
\hline Core Lake Karasie & 5 & $3.24-3.23$ & $\begin{array}{c}\text { wood, seeds, } \\
\text { tree moss }\end{array}$ & CAMS \# 71813 & $35610 \pm 40$ & $41014-40563(95.4 \%)$ \\
\hline Cross-section 6204 & 4 & 10.6 & wood & $\mathrm{Ki}-3370$ & $34500 \pm 250$ & $40329-39199(95.4 \%)$ \\
\hline Cross-section Ovrazhnyii - 2 & 7 & $3.9-3.8$ & wood & SOAN -627 & $30070 \pm 370$ & 35 317-33 $918(95.4 \%)$ \\
\hline Cross-section Akulinin & 8 & $3.65-3.6$ & peat & TIG - DVGU - 17 & $29430 \pm 475$ & $\begin{array}{c}34 \quad 892-32771(92.9 \%) \\
32 \quad 602-32 \quad 277(2.5 \%)\end{array}$ \\
\hline Cross-section 6204 & 4 & 9.1 & wood & $\mathrm{Ki}-3275$ & $27750 \pm 150$ & $31977-31273(95.4 \%)$ \\
\hline Cross-section Tikhangoy Bay & 6 & 12.5 & wood & $\mathrm{Ki}-2904$ & $27000 \pm 1500$ & $35464-28587(95.4 \%)$ \\
\hline Cross-section Akulinin & 8 & $3.35-3.3$ & peat & MAG - 341 & $22700 \pm 80$ & \begin{tabular}{|cccc}
27 & $262-26$ & 918 & $(88.7 \%)$ \\
26 & $707-26$ & 600 & $(4.7 \%)$ \\
26 & $541-26$ & 485 & $(2.0 \%)$ \\
\end{tabular} \\
\hline Cross-section 6276 & 10 & 1.0 & wood & $\mathrm{Ki}-2174$ & $18580 \pm 225$ & 22 974-22 $105(95.4 \%)$ \\
\hline Cross-section 6205 & 9 & 6.9 & wood & $\mathrm{Ki}-3293$ & $17990 \pm 200$ & $22368-21292(95.4 \%)$ \\
\hline Core 579 & 11 & 5.2 & humified loam & $\mathrm{Ki}-2166$ & $17840 \pm 200$ & 22 169-21 $021(95.4 \%)$ \\
\hline Cross-section Unashi & 12 & $3.3-3.4$ & wood & $\mathrm{Ki}-2917$ & $17400 \pm 125$ & $21403-20670(95.4 \%)$ \\
\hline Core Lake Karasie & 5 & $1.66-1.63$ & $\begin{array}{l}\text { seeds, wood, } \\
\text { tree moss }\end{array}$ & CAMS \# 73291 & $17160 \pm 40$ & $20856-20558$ (95.4\%) \\
\hline Cross-section 6205 & 9 & 5.7 & wood & $\mathrm{Ki}-3294$ & $14800 \pm 100$ & 18 269-17 $849(95.4 \%)$ \\
\hline Cross-section 6205 & 9 & 3.6 & wood & $\mathrm{Ki}-3298$ & $12300 \pm 100$ & $14867-14039(95.4 \%)$ \\
\hline Cross-section Unashi & 12 & $2.4-2.3$ & wood & SOAN - 288 & $11500 \pm 130$ & 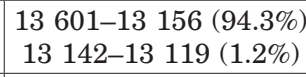 \\
\hline Core 508 & 13 & 4.5 & wood & $\mathrm{Ki}-2171$ & $9680 \pm 130$ & $\begin{array}{c}11391-11378(0.4 \%) \\
11337-10652(94.3 \%) \\
10621-10594(0.8 \%)\end{array}$ \\
\hline Cross-section 6205 & 9 & 1.8 & wood & $\mathrm{Ki}-3293$ & $9270 \pm 60$ & $\begin{array}{c}10642-10637(0.4 \%) \\
10582-10253(95.0 \%)\end{array}$ \\
\hline Cross-section 9119 & 14 & 2.1 & wood & - & $9250 \pm 70$ & $10581-10245(95.4 \%)$ \\
\hline Cross-section 9119 & 12 & 1.6 & wood & - & $8960 \pm 80$ & $\begin{array}{r}10247-9884(90.0 \%) \\
9865-9775(5.4 \%)\end{array}$ \\
\hline Core 9 & 15 & 6.5 & plant detritus & $\mathrm{Ki}-3688$ & $8900 \pm 60$ & $10205-9767(95.4 \%)$ \\
\hline $\begin{array}{l}\text { Cross-section Bolotisty } \\
\text { Stream }\end{array}$ & 18 & 3.2 & peat & LU - 8138 & $8620 \pm 90$ & 9 900-9 $462(95.4 \%)$ \\
\hline Cross-section 1438 & 16 & 1.7 & wood & MAG - 332 & $8180 \pm 80$ & $9425-8968(95.4 \%)$ \\
\hline Core 272 & 17 & $1.95-1.9$ & wood & SOAN - 7179 & $7995 \pm 45$ & $\begin{array}{c}9005-8698(92.0 \%) \\
8672-8649(3.5 \%)\end{array}$ \\
\hline Core Lake Karasie & 5 & $1.40-1.37$ & $\begin{array}{l}\text { seeds, wood, } \\
\text { charcoal }\end{array}$ & CAMS \# 73290 & $7550 \pm 40$ & $\begin{array}{c}8420-8309(86.6 \%) \\
8260-8210(8.9 \%)\end{array}$ \\
\hline Cross-section 4005 & 19 & 2.4 & plant detritus & $\mathrm{Ki}-2365$ & $7240 \pm 120$ & 8 091-8 188 (95.4\%) \\
\hline Cross-section 6010 & 20 & 1.7 & plant detritus & $\mathrm{Ki}-3269$ & $6660 \pm 70$ & $\begin{array}{c}7660-7636(3.7 \%) \\
7622-7427(91.8 \%)\end{array}$ \\
\hline Cross-section 4005 & 19 & 2.2 & plant detritus & $\mathrm{Ki}-2159$ & $6530 \pm 75$ & $\begin{array}{c}7427-7156(92.5 \%) \\
7 \quad 111-7072(2.4 \%) \\
7041-7031(0.5 \%)\end{array}$ \\
\hline Cross-section 6056 & 23 & 2.9 & plant detritus & $\mathrm{Ki}-3256$ & $6090 \pm 70$ & 6 786-7 $162(95.4 \%)$ \\
\hline Cross-section 6159 & 22 & 3.1 & wood & $\mathrm{Ki}-2141$ & $5360 \pm 75$ & $\begin{array}{l}6293-5991(93.1 \%) \\
(5965-5945)(2.3 \%)\end{array}$ \\
\hline Cross-section 6205 & 9 & 0.8 & peat & $\mathrm{Ki}-3372$ & $5120 \pm 80$ & 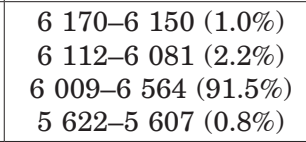 \\
\hline Core Lake Karasie & 5 & $1.04-1.03$ & $\begin{array}{l}\text { seeds, } \\
\text { charcoal }\end{array}$ & CAMS \# 71814 & $5050 \pm 40$ & $\begin{array}{c}5907-5710(91.4 \%) \\
5686-5662(4.1 \%)\end{array}$ \\
\hline
\end{tabular}


Table 4. Continued

\begin{tabular}{|c|c|c|c|c|c|c|}
\hline Cores and Cross-sections & $\begin{array}{l}\text { No on } \\
\text { Fig. } 3\end{array}$ & $\begin{array}{l}\text { Depth } \\
\text { [m] }\end{array}$ & $\begin{array}{l}\text { Dated } \\
\text { material }\end{array}$ & $\begin{array}{l}\text { Laboratory } \\
\text { number }\end{array}$ & ${ }^{14} \mathrm{C}$ age, $\mathrm{BP}$ & $\begin{array}{l}\text { Calibrated age range, } \\
\text { cal BP (probability) }\end{array}$ \\
\hline Core Lake Utinoye & 24 & $4.71-4.68$ & wood, charcoal & CAMS \# 73295 & $5000 \pm 80$ & $5905-5595(95.4 \%)$ \\
\hline Core Lake Karasie & 5 & $0.77-0.74$ & seeds & CAMS \# 74346 & $4890 \pm 40$ & $\begin{array}{c}5722-5580(93.0 \%) \\
5503-5489(2.5 \%)\end{array}$ \\
\hline Cross-section 1 706-1 & 25 & $1.89-1.86$ & buried soil & LU - 8780 & $4650 \pm 110$ & $\begin{array}{c}5593-5040(94.7 \%) \\
5002-4895(0.8 \%)\end{array}$ \\
\hline Cross-section Kazachka & 21 & 1.2 & wood & DVGU - TIG - 29 & $4472 \pm 75$ & $\begin{array}{l}5311-4951(86.4 \%) \\
4944-4875(9.0 \%)\end{array}$ \\
\hline Core Lake Karasie & 5 & $0.67-0.60$ & seeds & CAMS \# 73288 & $4300 \pm 40$ & $\begin{array}{c}4974-4823(94.8 \%) \\
4744-4736(0.7 \%)\end{array}$ \\
\hline Cross-section 9 031a & 26 & 2.4 & wood & $\mathrm{Ki}-3686$ & $4210 \pm 60$ & $\begin{array}{c}4865-4570(94.2 \%) \\
4550-4533(1.3 \%)\end{array}$ \\
\hline Cross-section Tikhangoy Bay & 6 & $1.25-1.20$ & peat & TIG - DVGU - 51 & $4195 \pm 50$ & $4850-4577(95.4 \%)$ \\
\hline Cross-section 1504 & 27 & $3.8-3.7$ & peat & $\mathrm{Ki}-1455$ & $4000 \pm 60$ & $\begin{array}{c}4796-4761(3.0 \%) \\
4693-4679(0.8 \%) \\
4643-4635(0.4 \%) \\
4626-4288(90.1 \%) \\
4272-4251(1.2 \%)\end{array}$ \\
\hline Core Lake Utinoye & 24 & $3.47-3.45$ & wood & CAMS \# 76800 & $3920 \pm 40$ & $\begin{array}{c}4515-4480(4.5 \%) \\
4444-4235(90.4 \%) \\
4195-4188(0.5 \%)\end{array}$ \\
\hline Core Lake Karasie & 5 & $0.45-0.43$ & seeds & CAMS \# 74344 & $3870 \pm 40$ & $\begin{array}{l}4 \quad 414-4224(82.5 \%) \\
4205-4 \quad 155(13.0 \%)\end{array}$ \\
\hline Cross-section Kiya & 30 & 0.95 & peat & $(\mathrm{SOAN}-4752)$ & $3720 \pm 100$ & $4405-3836(95.4 \%)$ \\
\hline Cross-section Ovrazhnyii - 2 & 7 & $2.1-2.0$ & wood & TIG - 41 & $3490 \pm 90$ & $\begin{array}{c}4060-4052(0.4 \%) \\
3985-3549(92.9 \%) \\
3535-3492(2.2 \%)\end{array}$ \\
\hline Cross-section 1706 - 1 & 25 & $0.73-0.7$ & buried soil & LU -8779 & $3020 \pm 100$ & $3447-2950(95.4 \%)$ \\
\hline Cross-section 1504 & 27 & $2.8-2.7$ & wood & MAG - 244 & $2770 \pm 60$ & $\begin{array}{c}3054-3048(0.4 \%) \\
3027-3019(0.6 \%) \\
3004-2755(94.5 \%)\end{array}$ \\
\hline Core Lake Utinoye & 24 & $2.23-2.21$ & plant detritus & CAMS \# 76799 & $2510 \pm 60$ & $\begin{array}{c}2744-2410(93.1 \%) \\
2388-2369(2.4 \%)\end{array}$ \\
\hline Cross-section $1508-1$ & 28 & $2.88-2.73$ & buried soil & LU - 7961 & $2460 \pm 100$ & $2755-2335(95.4 \%)$ \\
\hline Cross-section 6022 & 29 & 1.6 & plant detritus & $\mathrm{Ki}-3270$ & $2350 \pm 40$ & 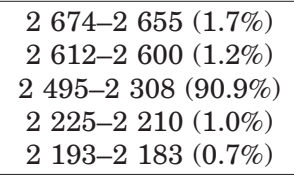 \\
\hline Cross-section Ovrazhnyii - 2 & 7 & $1.05-0.95$ & wood & TIG - 1966 & $2220 \pm 60$ & $\begin{array}{l}2340-2051(94.8 \%) \\
2015-2009(0.7 \%)\end{array}$ \\
\hline Cross-section 4005 & 19 & 1.8 & wood & $\mathrm{Ki}-3678$ & $1930 \pm 40$ & $\begin{array}{c}1979-1967(1.6 \%) \\
1943-1737(93.8 \%)\end{array}$ \\
\hline Cross-section 1508 - 1 & 28 & $1.52-1.44$ & buried soil & $\mathrm{LU}-7960$ & $1930 \pm 100$ & $\begin{array}{c}1979-1967(1.6 \%) \\
1943-1737(93.8 \%)\end{array}$ \\
\hline Borehole Lake Utinoye & 24 & $1.30-1.27$ & wood, leaves & CAMS \# 76798 & $1810 \pm 60$ & $\begin{array}{c}1865-1856(1.0 \%) \\
1833-1549(94.5 \%)\end{array}$ \\
\hline Cross-section Ovrazhnyii - 2 & 7 & $0.65-0.6$ & peat & SOAN - 554 & $1450 \pm 50$ & $1413-1283(95.4 \%)$ \\
\hline Cross-section Tikhangoy Bay & 6 & $0.55-0.5$ & peat & SOAN - 136 & $1375 \pm 75$ & $\begin{array}{c}1407-1172(90.9 \%) \\
1164-1121(3.8 \%) \\
1093-1079(0.8 \%)\end{array}$ \\
\hline Cross-section 1508 - 1 & 28 & $0.65-0.57$ & buried soil & LU - 7959 & $1360 \pm 60$ & $\begin{array}{c}1376-1174(95.4 \%) \\
1158-1150(0.7 \%) \\
1 \quad 139-1131(0.6 \%)\end{array}$ \\
\hline
\end{tabular}

\section{PINUS KORAIENSIS POLLEN IN THE SEDIMENTS OF MIS 1 \\ (11 $700 \mathrm{cal} \mathrm{BP}$ - to present)}

The Holocene in the south of the Russian Far East is subdivided into three time zones, 11 700-8200 cal BP (early Holocene),
8200-4200 cal BP (middle Holocene), and 4200 cal BP to the present (late Holocene), based on pollen data (Korotky, 2002).

From 11700 to 8200 cal BP, Pinus koraiensis pollen fossil has been found at the lower reaches of the Sorochevka River, in core 508, 

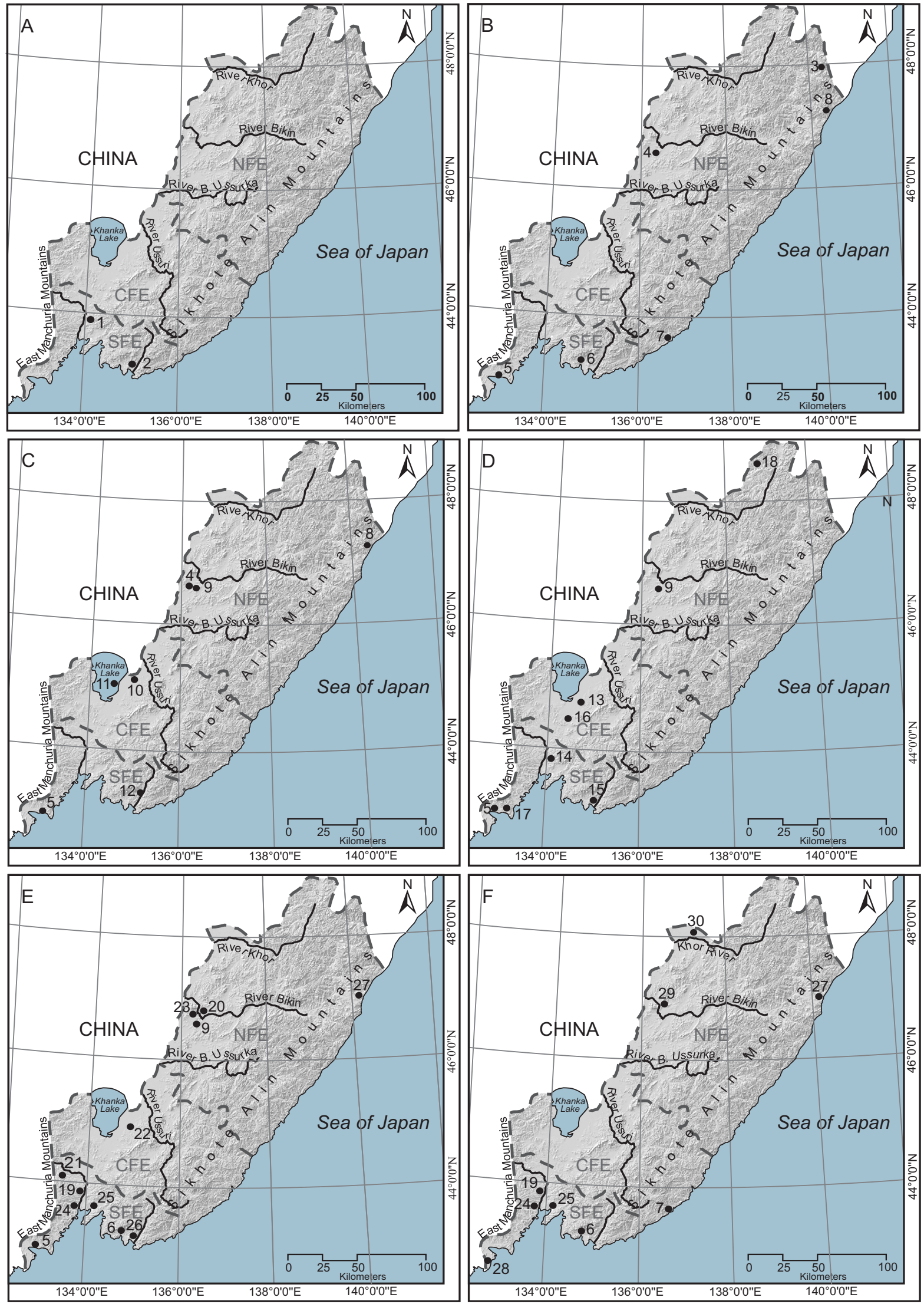

Fig. 3. Locations and ages in the Pinus koraiensis fossil record in the southern part of the Russian Far East (Korotky et al., 1980; Pavlyutkin et al., 1984; Korotky, 2002; Pavlyutkin and Belyanina, 2002; Bazarova et al., 2008; Mikishin et al., 2008; Anderson et al., 2017; Belyanin and Belyanina, 2018, 2020; Belyanin et al., 2018, 2019). Numbers 1-30 - locations of cores and sections. Time intervals: A. MIS 5 (127 000-71 000 BP); B. MIS 3 (57 000 BP-28 000 cal BP); C. MIS 2 (28 000-11 700 cal BP); MIS 1: D. The early Holocene (11 700-8200 cal BP); E. The middle Holocene (8200-4200 cal BP); F. The late Holocene (4200 cal BP to the present). For the designation of cross-sections and cores on the map, see Table 3 


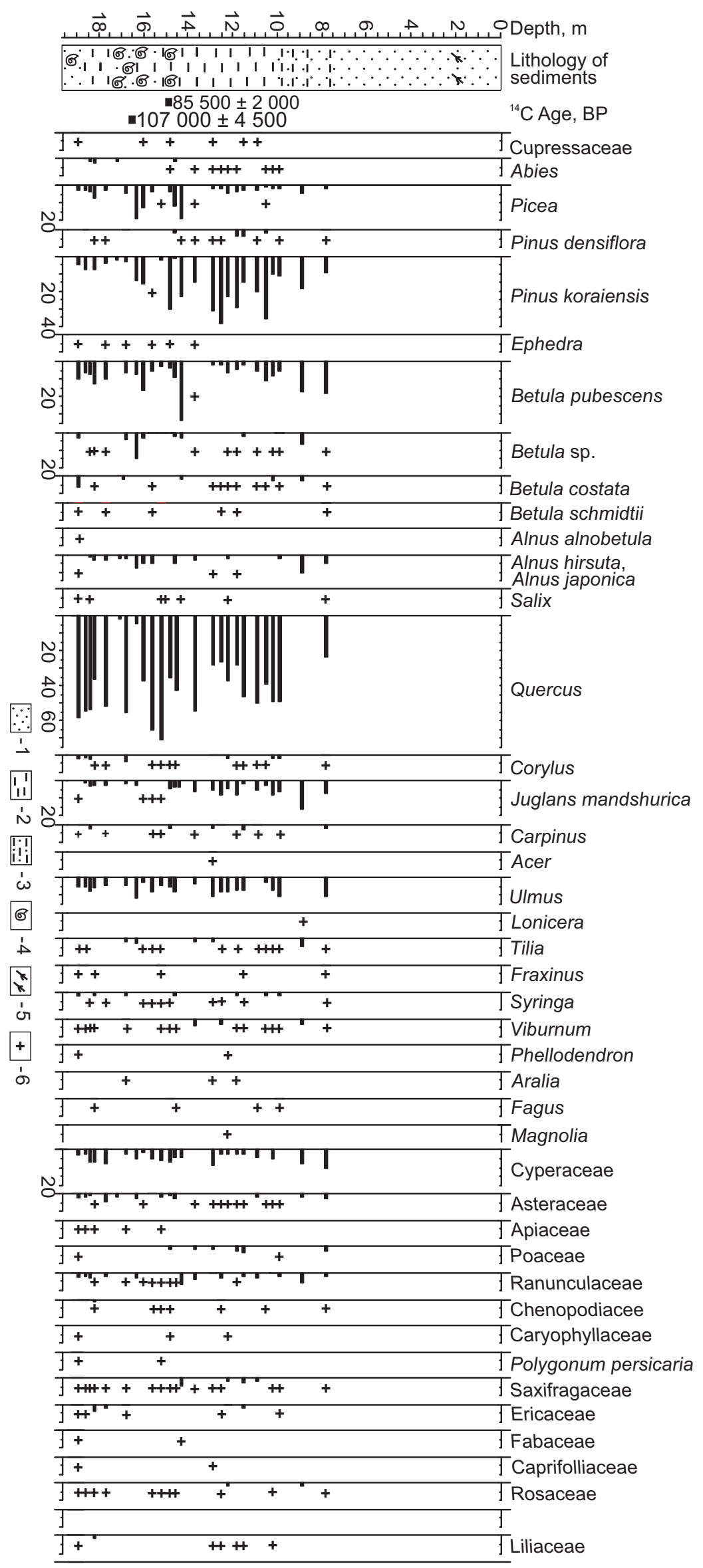

Fig. 4. Palynological diagram from core 11 in the floodplain of the Partizanskaya River. 1 - sand, 2 - loam, 3 - sandy loam, $4-$ marine shells, 5 - plant detritus, 6 - taxa present in the assemblage in amounts less than $3 \%$ (Pavlyutkin and Belyanina, 2002) 


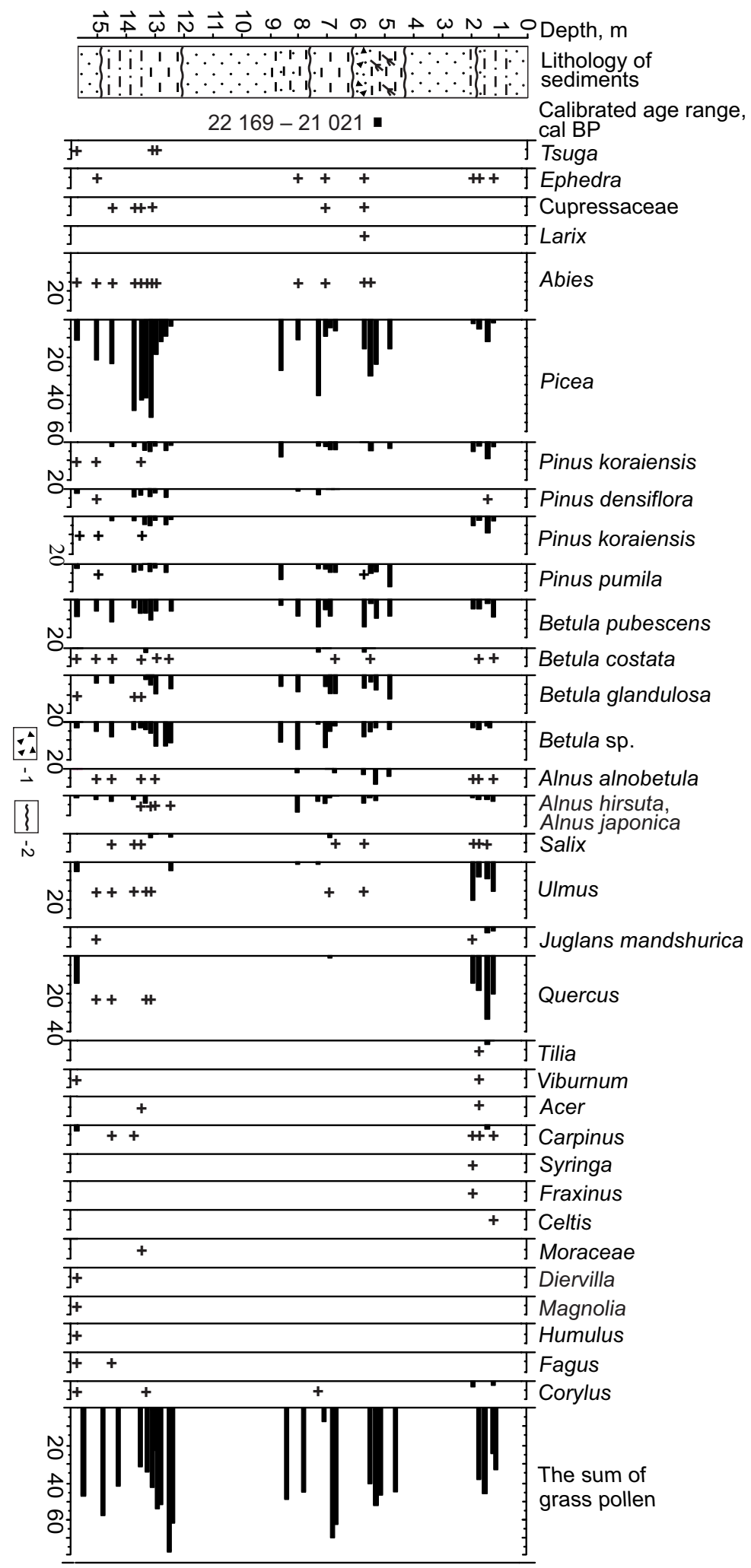

Fig. 5. Palynological diagram from core 579 from the bottom sediments of Lake Khanka. 1 - gravel, 2 - gap in the sediments. For explanation see Fig. 4 (Belyanin and Belyanina, 2012)

CFE (11 337-10652 cal BP) (Belyanin and Belyanina, 2020) (Fig. 6), at the lower reaches of the Kontrovod River, in cross-section 6 205, NFE $10582-10253$ cal BP), at the mouth of the Popovka River, in cross-section 9 119, SFE (10 581-10 $245 \mathrm{cal}$ BP and 10 247-9884 cal BP), at the mouth of the Partizanskaya River, in core 9, SFE (10 205-9767 cal BP) (Pavlyutkin and Belyanina, 2002), at the Bolotisty Stream, NFE (9900-9462 cal BP) (Belyanin et al., 2018), at the lower reaches of the Chernigovka River, in cross-section 1 438, CFE (9425-8968 


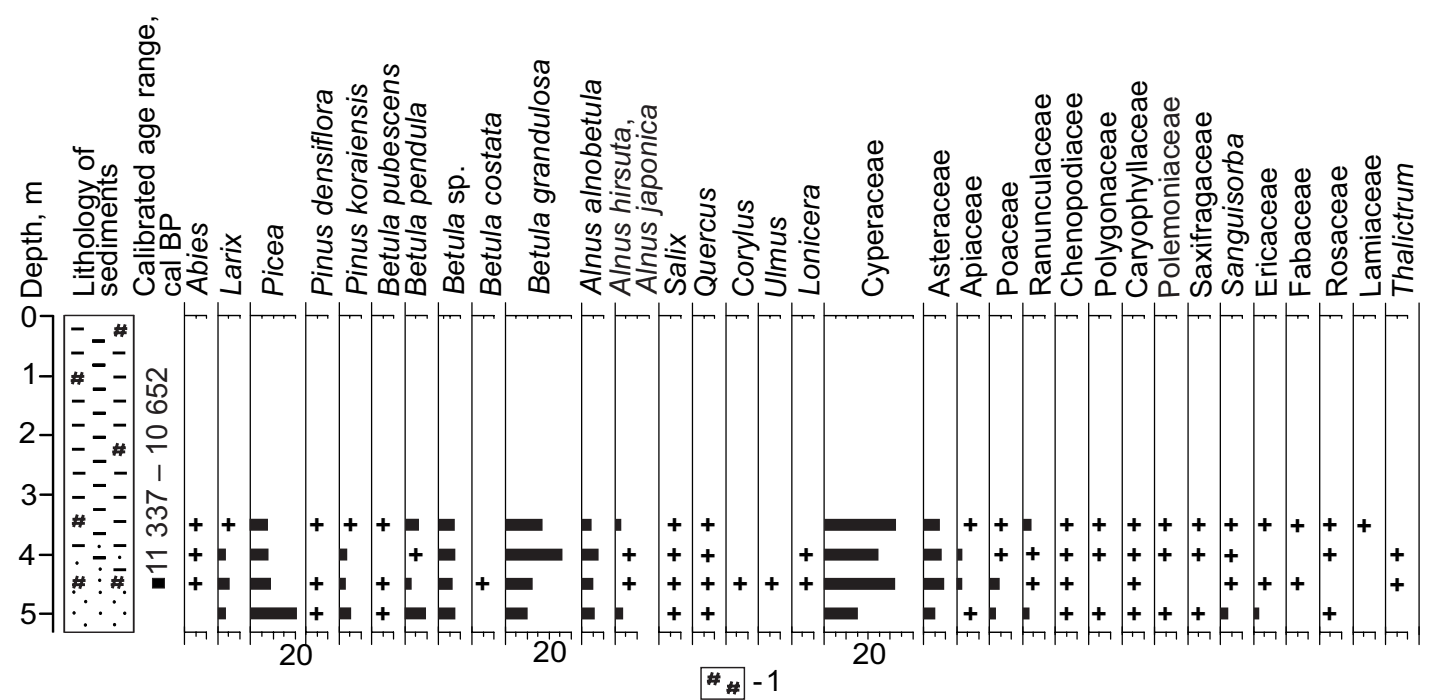

Fig. 6. Palynological diagram from core 508 in the floodplain of the Sorochevka River 1 - wood. For explanation see Fig. 4 (Belyanin and Belyanina, 2020)

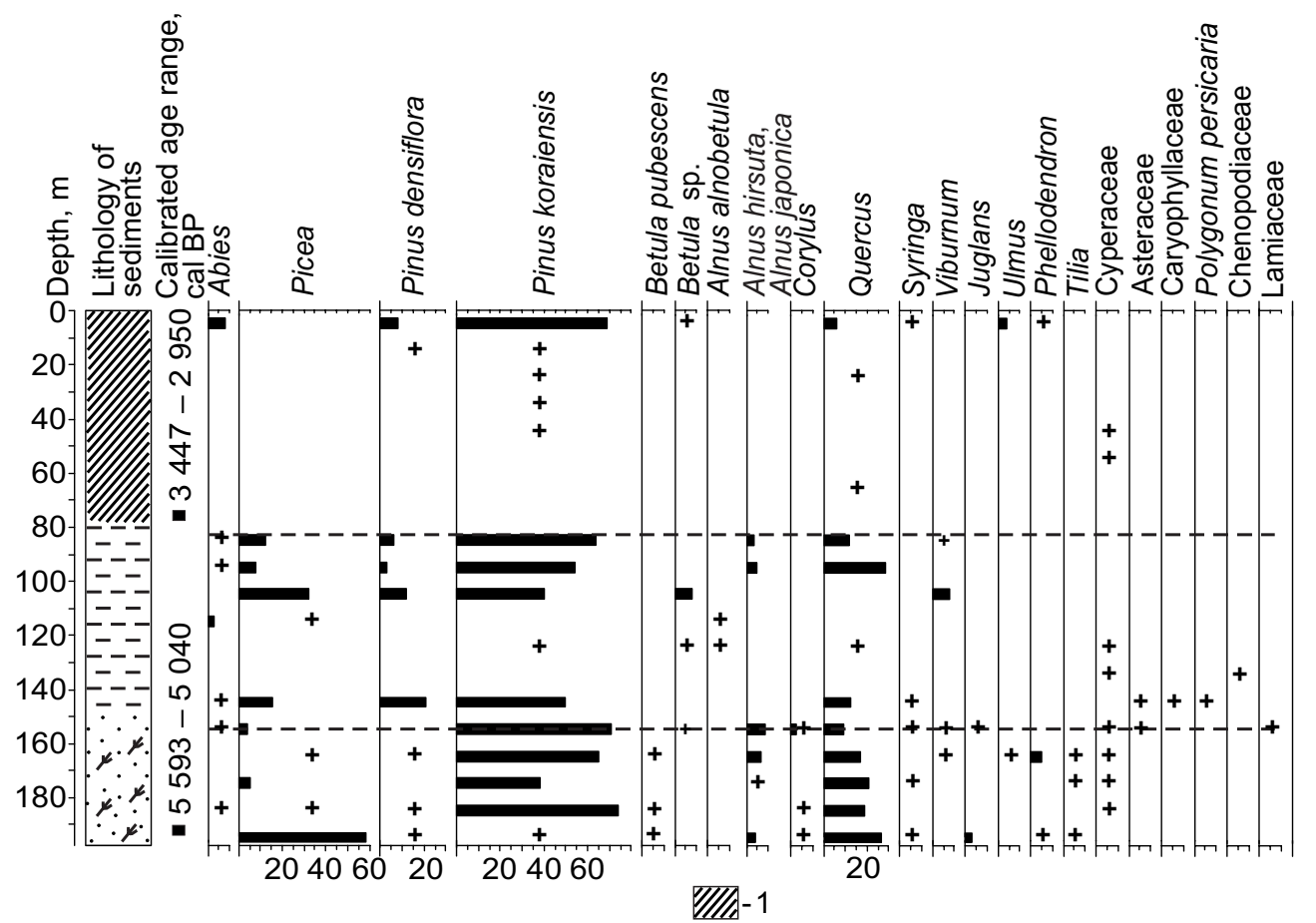

Fig. 7. Palynological diagram from cross-section $1706-1$ in the floodplain of the Knevichanka River. 1 - soil. For explanation see Fig. 4

cal BP) (Korotky et al., 1980), at the mouth of the Vinogradnaya River, in core 272, SFE (9005-8698 cal BP) (Mikishin et al., 2008) and in the core of Lake Karasie, SFE (8420-8309 cal BP) (Anderson et al., 2017).

From 8200 to 4200 cal BP, Pinus koraiensis pollen fossil has been reported from many sites, such as the lower reaches of the Razdolnaya River, in cross-section 4 005, SFE (8091$8188 \mathrm{cal} \mathrm{BP}$ and 7427-7156 cal BP), SFE (Pavlyutkin and Belyanina, 2002), at the lower reaches of the Alchan River in cross-section
6010 (7622-7427 cal BP), NFE (Belyanin and Belyanina, 2018), at the lower reaches of the Burlitovka River in cross-section 6056 (6786-7162 cal BP), NFE (Belyanin and Belyanina, 2018), at the Sorochevka River Valley in cross-section 6159 (6293-5991 cal BP), at the lower reaches of the Kontrovod River in cross-section 6205 (6009-6564 cal BP), NFE (Belyanin and Belyanina, 2018), NFE, in Lake Karasie (5907-5710 cal BP, 5722-5580 cal BP, 4850-4938 cal BP, 4974-4823 cal BP and 4414-4224 cal BP), SFE (Anderson et al., 


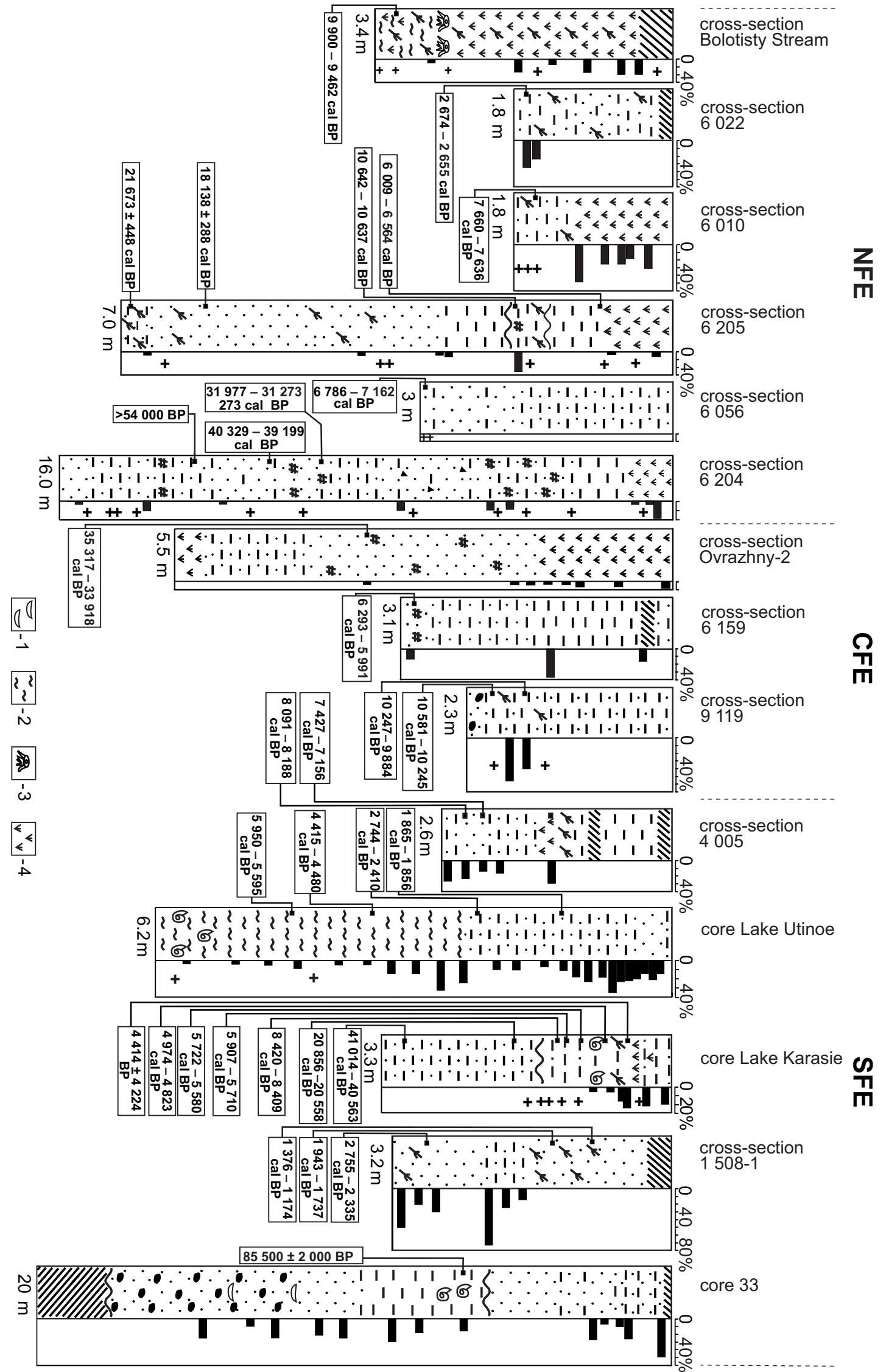

Fig. 8. The presence of Pinus koraiensis pollen in assemblages in MIS 5 (127 000-71 000 BP), MIS 3 (57 000 BP-28 000 cal BP), MIS 2 (28 000-11 $700 \mathrm{cal} \mathrm{BP})$, and MIS 1 - early Holocene (11 700-8200 cal BP), middle Holocene (8200-4200 cal BP) and late Holocene (4200 cal BP to the present) sediments in the south of the Russian Far East. 1 - shell detritus, 2 - mud, 3 stump horizon, 4 - peat. For explanation see Figs 4, 5, 6, 7 (Pavlyutkin and Belyanina, 2002; Mikishin et al., 2008; Anderson et al., 2017; Belyanin et al., 2018; Belyanin and Belyanina, 2018, 2020) 


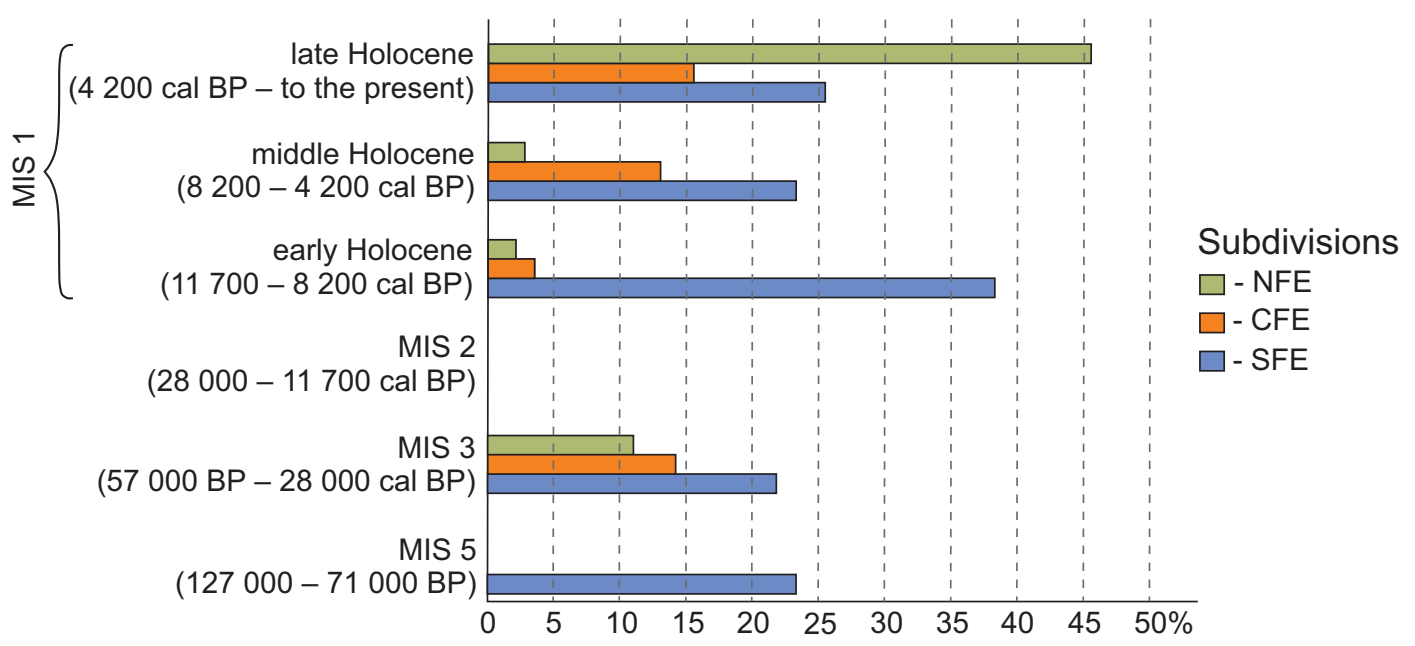

Fig. 9. Average percentage of Pinus koraiensis fossil pollen in each division in the south of the Russian Far East in MIS 5 (127 000-71 000 BP), MIS 3 (57 000 BP - 28000 cal BP), MIS 2 (28 000-11 700 cal BP), and MIS 1 - early Holocene (11 700$8200 \mathrm{cal} \mathrm{BP}$ ), middle Holocene (8200-4200 cal BP) and late Holocene (4200 cal BP to the present) (Korotky et al., 1980; Pavlyutkin et al., 1984; Korotky, 2002; Pavlyutkin and Belyanina, 2002; Bazarova et al., 2008; Mikishin et al., 2008; Anderson et al., 2017; Belyanin and Belyanina, 2018, 2020; Belyanin et al., 2018, 2019)

2017), at Lake Utinoe (5905-5595 cal BP and 4444-4235 cal BP), SFE (Anderson et al., 2017), at the Knevichanka River Valley in cross-section 1 706-1 (5593-5040 cal BP), SFE (Fig. 7), on the floodplain of the Partizanskaya River in cross-section 9 031a (4865-4570 cal BP), SFE (Pavlyutkin and Belyanina, 2002), at the mouth of the Venyukovka River in crosssection 15041 504, NFE (4626-4288 cal BP) (Korotky, 2002), in the valley of the Kazachka River in the Kazachka cross-section (53114951 cal BP), CFE (Pavlyutkin et al., 1984), and in the cross-section of the Tikhangou Bay (4850-4577 cal BP), SFE (Korotky, 2002).

From 4200 cal BP to the present day, Pinus koraiensis pollen fossil has been encountered at the interfluve of the Khor and Kiya rivers, in Kiya cross-section, NFE (4405-3836 cal BP) (Bazarova et al., 2008), at the Neprimetnaya Bay in cross-section Ovrazhnyii-2 (3985-3549 cal BP, 2340-2051 cal BP and 1413-1283 cal BP) (Korotky, 2002), at the Knevichanka River Valley, in cross-section 1 706-1, SFE (34472950 cal BP), at the mouth of the Venyukovka River in cross-section 1 504, NFE (3004-2755 cal BP) (Korotky, 2002), in Lake Utinoye, SFE (2744-2410 cal BP and 1833-1549 cal BP) (Anderson et al., 2017), at the mouth of Tumen River in cross-section 1 508-1, SFE (2755-2335 cal BP, 1943-1737 cal BP, 1376$1174 \mathrm{cal} \mathrm{BP}$, and $1220-1340 \mathrm{cal} \mathrm{BP}$ ) (Belyanin et al., 2019), at the lower reaches of the Alchan River, in cross-section 6 022, NFE (2495-2308 cal BP), at the lower reaches of the Razdolnaya River, in cross-section 4 005, SFE (1943-1737 cal BP) (Pavlyutkin and Belyanina, 2002), and in the cross-section of the Tikhangoy Bay, SFE (1 407-1 172) (Korotky, 2002).

\section{DISCUSSION}

The available palynological and chronological data (Tab. 4) allow us to reconstruct the changes in the distribution of Pinus koraiensis in the south of the Russian Far East during MIS 5 (127 000-71 000 BP), MIS 3 (57000 BP -28000 cal BP), MIS 2 (28 000-11 700 cal BP), and MIS 1 (11700 cal BP - to present).

As a result of average annual temperatures increasing by $1.7-2.0^{\circ} \mathrm{C}$ in MIS 5 compared with the present values in the south of the Russian Far East (Velichko, 2012), a significant change occurred in the structure of vegetation, including a noticeable displacement of the range of Pinus koraiensis to the north. Although the number of MIS 5 samples is limited, its palynological record is abundant with Pinus koraiensis pollen fossil (Pavlyutkin and Belyanina, 2002). According to this pollen record, Pinus koraiensis dominated in the vegetation of MIS 5 in the south of the Russian Far East (Figs 8, 9). In that time, the mixed forests with Pinus koraiensis, Pinus densiflora, Quercus, Ulmus, Juglans, Carpinus, Phellodendron, Tilia, Cupressaceae families, and other broad-leaved plants dominated in the region.

In the south of the Russian Far East the period of MIS 3 refers to Chernoruch'inskii 
Stage by the regional scheme (Korotky, 2002). This period is characterised by small climatic fluctuations in the region. According to pollen reports (Korotky, 2002; Anderson et al., 2017; Belyanin and Belyanina, 2018), Pinus koraiensis grew in birch-fir forests in subregions SFE and CFE in the south of the Russian Far East during MIS 3. In SFE, it was the dominant species in birch-deciduous forests.

Apparently, the small amount of data obtained on Pinus koraiensis pollen in the region during MIS 5 (127 000-71000 $\mathrm{BP}$ ) and MIS $3(57000 \mathrm{BP}-28000$ cal BP) is associated with, among other things, a long period of aerobic conditions, which led to a significant depletion of the taxonomic composition of fossil pollen. Contact with oxygen might have also fostered the bacterial and fungal degradation of sporopollenin (Elsik, 1971; Havinga, 1971). Moreover, the alternation of wet and dry cycles, which are common for several types of soils, can cause mechanical damage to pollen grains, presumably due to flexing with repeated shrinking and swelling (Campbell, 1994).

Cooling of the climate in MIS 2 caused a decline of plant diversity in the south of the Russian Far East and forced the migration of Pinus koraiensis southward where better climate and habitat conditions were found. The abundant pollen record obtained from the sediments, proved that during MIS 2 Pinus koraiensis disappeared from the south of the Russian Far East. Principal pollen taxa (Korotky, 2002; Anderson et al., 2017; Belyanin and Belyanina, 2018) suggest that the annual mean temperatures of about $5^{\circ} \mathrm{C}$ were colder than nowadays, and annual mean precipitation was less than at present. This is consistent with the climatic stratigraphic scheme of the south of the Russian Far East (Korotky et al., 1980; Korotky, 2002).

Most of the Pinus koraiensis range during MIS 2 was confined to the south of the Korean Peninsula (Kong et al., 2014) and covered Honshu, Shikoku, and Kyushu, islands of Japan (Miki, 1956; Aizawa et al., 2012), as lower sea level separated them from the continent in a narrow strait (Tsukada, 1984; Ohshima, 1990; Igarashi, 1993; Dobson and Kawamura, 1998; Nakamura and Krestov, 2005).

A common range of Pinus koraiensis on the Korean Peninsula, Northeast China, and Japan Islands is confirmed by the results of Pinus koraiensis phylogeographic studies.
The cpDNA variation indicates that there was no difference between the populations on the Asian continent and those in the Japanese archipelago. Continental populations do not show mtDNA diversity, despite the current extensive range and large populations of the species. Despite that Pinus koraiensis is seldom encountered in Japan, the Japanese populations show greater levels of mtDNA diversity. Higher mtDNA diversity (Aizawa et al., 2012) and numerous remains of Pinus koraiensis macrofossils recovered at various sites in Japan and dated to the Pleistocene (Miki, 1956) suggest that the Japanese Archipelago once served as a refuge to a much larger Pinus koraiensis population with a more extensive range than today. The presence of the single mtDNA haplotype of Pinus koraiensis on the Asian continent suggests that the present populations could have expanded from a single refuge population after MIS 2 (Aizawa et al., 2012).

Dated pollen records from northeast China indicate that Pinus koraiensis was an important component of coniferous forests, which prevailed in the region before MIS 2. During MIS 2, Pinus koraiensis populations in the region underwent great reductions in the range, but they did not disappear completely. Small populations survived in the refuge, which was located on alluvial lowlands and plains, and in mountain ranges during the cold and dry MIS 2 (Kremenetski et al., 1998).

This decline of Pinus koraiensis is consistent with climatic and palaeobotanical data. The maps drawn for MIS 2 indicate that temperate-boreal mixed forests in northeast China, which were overlapped by modern forests dominated with Pinus koraiensis disappeared completely during MIS 2 (Harrison et al., 2001; Qiu et al., 2011).

Probably, not only low temperatures, but also aridity (Kremenetski et al., 1998) was the limiting factor for the survival of Pinus koraiensis during MIS 2. During MIS 2, the East Asian summer monsoon weakened and then intensified in response to the changes in insolation in the northern hemisphere (Cosford et al., 2010). In this case, during the coldest periods of MIS 2, which in the south of the Russian Far East were recorded from 25300 to $19300 \mathrm{cal} \mathrm{BP}$, from 14700 to $13300 \mathrm{cal} \mathrm{BP}$ and from 12700 to 11700 cal BP (Korotky, 2002), the range of Pinus koraiensis could be 
preserved in the refuge in the Changbai Mountains and in the Xiaoxingan Ridge (Bai et al., 2010; Qiu et al., 2011). Apparently, Pinus koraiensis migrated from these refuge areas to the south of the Russian Far East during warming in early Holocene (Korotky, 2002).

At the same time, it should be noted that during maximum cooling of MIS 2 from 25300 to $19300 \mathrm{cal} \mathrm{BP}$ (Korotky, 2002), the northern border of coniferous-deciduous forests, in which Pinus koraiensis is the main edificator, was located at about $30^{\circ} \mathrm{N}$ on the Asian continent, and at about $35^{\circ} \mathrm{N}$ on the islands of Japan. The pollen of Pinus koraiensis could not be transferred from the refuge in the Changbai Mountains and Xiaoxingan Range (Bao et al., 2015) to the south of the Russian Far East, since most of it is deposited from pollen rain within $58 \mathrm{~km}$ of the source (Ledig, 1998). The above refuges are located at a distance of 200 and $600 \mathrm{~km}$ from the south of the Russian Far East, respectively. Taken into account the period of time, which passed since MIS 2 and the rate at which Pinus koraiensis can expand its range, it is possible that the modern population in the south of the Russian Far East could have originated from an isolated group of the trees in the Changbai Mountain region (Aizawa et al., 2012).

The migration of Pinus koraiensis, the wingless seeds of which cannot be carried by wind (Lanner, 1998) takes place mainly with the help of animals. Nutcracker (Nucifraga caryocatactes) is the most important distributing agent, and it can carry a single seed per trip up to 100 Pinus koraiensis nuts (Omelko and Omelko, 2017) for a distance of up to 15 km (Formozov, 1976; Mattes, 1985; Hutchins et al., 1996). The Eurasian nuthatch (Sitta europaea) can carry a single seed per trip for distances less than $50 \mathrm{~m}$, but it needs nutcrackers to open the cones and to expose the seeds before they can get the seeds and sometimes they take seeds from the soil (Hutchins et al., 1996). Manchurian squirrel (Sciurus vulgaris mantchuricus) transfers the nuts for a distance of about $0.6 \mathrm{~km}$ (Miyaki, 1987). At the same time, the migration of Pinus koraiensis is often limited by the available seed sources, and this would be particularly true for new species encroaching into existing forest vegetation (Iverson et al., 2004).

The beginning of the Holocene at $11700 \mathrm{cal}$ BP (Walker et al., 2012) was marked by a sharp warming that resulted in conspicuous changes in the structure of the vegetation. Pinus koraiensis responded relatively quickly to the changing environment. Significant warming caused the active migration of Pinus koraiensis from the refuge in the Changbai Mountains and in the Xiaoxingan Range (Bai et al., 2010; Qiu et al., 2011) to the south of the Russian Far East. According to the palynological data obtained from the south of the Russian Far East (Pavlyutkin et al., 1984; Korotky, 2002; Pavlyutkin and Belyanina, 2002; Mikishin et al., 2008; Anderson et al. 2017; Belyanin et al., 2018; Belyanin and Belyanina, 2018, 2020), dark coniferous (spruce and fir) forests, very diverse in structure, were widespread in the region in the early Holocene. Such vegetation provides good conditions for the growth of Pinus koraiensis. In contrast, another cold tolerant species of Pinus subgen. Haploxylon - Pinus pumila cannot grow under the canopy of a closed forest. This species is photophilous and can hardly compete with other trees and shrubs in the shade under the canopy of a closed forest (Kabanov, 1977). Therefore, under the conditions of the onset of warming, Pinus pumila was forced to retreat to the north and to the upper belt of the mountains.

During early Holocene (from 11700 to 8200 cal BP), Pinus koraiensis was widespread in the south of the Russian Far East. Significant percentage of Pinus koraiensis in the pollen assemblages can indicate that the climate of the early Holocene was milder than in MIS 2 , and a stable climatic condition was maintained at the beginning of MIS 1 .

Nevertheless, in the early Holocene the presence of Pinus koraiensis in the forests of the NFE subdivision was still insignificant. Pinus koraiensis grew mainly together with Betula glandulosa, Betula pubescens, Alnus alnobetula, Alnus hirsuta, Ulmus davidiana, Larix gmelinii, Picea jezoensis and Picea koraiensis. The broadleaved species, such as Ulmus davidiana and Quercus mongolica were seldom encountered in this subregion (Belyanin and Belyanina, 2018). In the CFE subdivision Pinus koraiensis was codominant in the vegetation among Picea jezoensis, Larix gmelinii, Abies nephrolepis, Betula glandulosa, Betula pubescens, Quercus mongolica, Corylus heterophylla, Ulmus laciniata and Ulmus davidiana. In the SFE subdivision Pinus koraiensis became one of the main forest-forming species in the forests with Quercus mongolica, Ulmus 
laciniata, Ulmus davidiana, Juglans mandshurica, Carpinus cordata, Tilia amurensis, Tilia mandshurica, Fraxinus mandshurica, Corylus heterophylla, Abies holophylla, Abies nephrolepis, Picea koraiensis and Picea jezoensis. This is strongly confirmed by the pollen records where the proportion of the Pinus koraiensis pollen in the SFE subdivision is notably greater than in the sediments from the NFE and CFE subdivisions (Pavlyutkin et al., 1984; Mikishin et al., 2008; Anderson et al., 2017).

The higher proportion of Pinus koraiensis in the early Holocene pollen records documented in the SFE subdivision suggests that this species migrated to the south of the Russian Far East from the Korean Peninsula, where the climate was more favourable for the growth of Pinus koraiensis even at the beginning of MIS 2 (Kong et al., 2014). The displacement of the Pinus koraiensis range to the north in the early Holocene might indicate that the climate in the early Holocene was milder than in MIS 2, and a more stable climatic condition was maintained. This interval corresponds to the time of coniferous - broadleaved forest recovery in the south of the Russian Far East after the MIS 2 epoch had come to its end. Vegetation of the region obtained gradually its modern appearance. Pollen data for northeast China also show that Pinus koraiensis grew in the region in the early Holocene, expanding outwards concentrically from the Changbai Mountain region (Ren and Zhang, 1998).

Pollen records for the early Holocene obtained from the south of the Russian Far East are also in good agreement with those in the Lake Baikal region, where the expansion of other species of Pinus subgen. Haploxylon - species Pinus sibirica (Siberian stone pine) began $\sim 11000 \mathrm{cal}$ BP (Bezrukova et al., 2005). These facts correspond well with evidence on the change of global climate and environment amelioration at that time (Korotky, 2002; Anderson et al., 2017; Belyanin et al., 2018) that led to essential changes in the structure of vegetation.

The transition from the early Holocene (from 11700 to $8200 \mathrm{cal} \mathrm{BP}$ ) to the middle Holocene (from 8200 to 4200 cal BP) was marked by a short-term cooling at about 8200 cal BP (Korotky, 2002) that resulted in Pinus koraiensis being replaced in part by conifers plants more tolerant to cold. In the mountain ecosystems, in particular on the north-facing slopes, Pinus koraiensis together with broadleaved species gave the way to fir and spruce. But the presence of Pinus koraiensis remained considerable in the $\mathrm{SFE}$ and $\mathrm{CFE}$ subdivisions.

According to the data published by A.A. Velichko (2012), global temperatures in the Holocene optimum were $0.7-1^{\circ} \mathrm{C}$ higher than those today. Probably, in the south of the Russian Far East the rise in the average annual temperature could have been as great as $3-5^{\circ} \mathrm{C}$ and the amount of precipitations was between 900-1600 mm / year (Mikishin et al., 2019). A maximum in climate warming from 8600 to 5500 cal BP (Korotky et al., 1980; Korotky, 2002) led to the shift of broadleaved plants and some ranges of coniferous plants northward by 200-400 km (Khotinsky, 1977).

As a result of the rise of mean annual temperatures, Pinus koraiensis increased notably its presence in the south of the Russian Far East (Belyanin and Belyanina, 2019). Its fossil pollen was recorded in each subregion in the south of the Russian Far East. Plant formations were more diversified in species composition compared with those of present days. It should be noted that in a drier climate in the adjacent mountains in northeastern China, near Lake Sihaylongwan, Pinus koraiensis began to spread from $\sim 6600 \mathrm{cal} \mathrm{BP}$, where it became one of the main forest-forming species at $\sim 5200$ cal BP (Stebich et al., 2015), and in the Lake Qingbohu (Jingbo) region Pinus koraiensis began to spread from 5400 cal BP (Li et al., 2011). Similar processes are known to have taken place in the Lake Baikal region where Pinus sibirica was one of the chief forest-forming species at $\sim 6800$ cal BP (Danko et al., 2009).

Cooling, which started at the transition from the middle Holocene to the early Holocene about 4200 cal BP, resulted in a competition between Pinus koraiensis and species more tolerant to cold like Picea jezoensis and Abies nephrolepis that led to a reduction of Pinus koraiensis in the vegetation. The general trend towards cooling was interrupted by short-term warning from 4700 to 3500 cal BP (Korotky, 2002). It was marked by an increase in the role of Pinus koraiensis in the vegetation. It was a codominant species in the plant formations with Pinus densiflora, Abies holophylla, Abies nephrolepis, Quercus mongolica, Ulmus laciniata, Ulmus davidiana, Carpinus cordata, Fraxinus mandshurica, Syringa, and other warm-tolerant trees. The subsequent cooling periods from 11500 to 
$10100 \mathrm{cal} \mathrm{BP}$, from 9300 to $8800 \mathrm{cal} \mathrm{BP}$, from 5300 to $4700 \mathrm{cal} \mathrm{BP}$, from 3300 to $2600 \mathrm{cal} \mathrm{BP}$, and from 700 to $100 \mathrm{cal} \mathrm{BP}$ (Korotky, 2002) led to a decrease in the role of Pinus koraiensis in the vegetation, which had been largely replaced by Abies and Picea, along with the lowering of its altitudinal range (tree line).

Similar processes took place in the Lake Baikal region from 2600 to $2000 \mathrm{cal} \mathrm{BP}$, when forests with Siberian stone pine gained substantial territories in the area (Bezrukova et al., 2013). Another short-term warming from 1700 to 700 cal BP (Korotky, 2002) led to the expansion of Pinus koraiensis and broadleaved plants in the south of the Russian Far East. It seems likely that Pinus densiflora, Betula pubescens, Betula costata, Abies holophylla, Carpinus cordata, and some other plants were present as codominant (Belyanin and Belyanina, 2012, 2018; Belyanin et al., 2019).

Spatial fluctuations of the Pinus koraiensis range occurred in the late Holocene (from 4200 cal BP to the present day) against the background of an unstable climate and gradually decreasing heat supply (Wanner et al., 2008). Palynological data (Pavlyutkin et al., 1984; Korotky, 2002; Pavlyutkin and Belyanina, 2002; Bazarova et al., 2008; Mikishin et al., 2008; Anderson et al., 2017; Belyanin and Belyanina, 2018, 2020) suggest some wave-like fluctuations of the proportion of Pinus koraiensis in the vegetation.

Apparently, an anthropogenic impact began to influence the distribution of Pinus koraiensis in the south of the Russian Far East in the Neolithic epoch. Pollen data in the Iman River valley, the NFE subdivision in the south of the Russian Far East, indicate significant vegetation changes during the periods of occupation at $5000 \mathrm{cal} \mathrm{BP}$ and $4000 \mathrm{cal} \mathrm{BP}$. They reflect fire clearance of taiga forests for new pastoral lands and/or wood cutting used for archaeologically documented log houses (Chlachula et al., 2015).

In the cultural layers, corresponding to the Almazinka Culture (4580-3530 cal BP) and the Dal'nyy Kut Culture (2910-2410 cal BP), progressive valley vegetation associated with the dominance of light-demanding Phellodendron thickets and a forest-steppe with Betula pubescens and Asteraceae, respectively have been found. A change from a mixed broadleaved forest with Pinus koraiensis to a semi-open forest and steppe-parklands also took place. The latter was interpreted as a result of a direct anthropogenic impact on the pristine vegetation (Chlachula et al., 2015).

At the beginning of the $1890 \mathrm{~s} \mathrm{AD}$ the south of the Russian Far East was populated by the Russians. According to the records of that time, broadleaved-Pinus koraiensis forests in the south of the Russian Far East covered an area of about $65000 \mathrm{~km}^{2}$ (Petropavlovsky et al., 1985). By today, the size of such areas has decreased by $33000 \mathrm{~km}^{2}$ (Petropavlovsky et al., 1985; Nakamura and Krestov, 2005). Extensive felling, fires, strong winds, the proliferation of insect pests contributing to the change of deciduous forests with Pinus koraiensis into simpler secondary plantations are the main reasons for the decrease of forest areas (Ivanov and Shashenok, 2018). The area formerly covered with broadleaved-Pinus koraiensis forests is now occupied by secondary Betula pubescens, Larix dahurica, Populus tremula forests formed mainly after logging and/or single fires, also by secondary Quercus mongolica forests $\left(12000 \mathrm{~km}^{2}\right)$ formed after logging and regularly repeated fires, especially around settlements, and by near agricultural lands (about $15000 \mathrm{~km}^{2}$ ) (Nakamura and Krestov, 2005). At the same time, the remaining primary forests with Pinus koraiensis continue to experience the extreme stress caused by a growing anthropogenic pressure and sharp climate changes.

The maps of potential vegetation (Kolesnikov, 1954, 1956) and bioclimatic indices (Grishin, 1995) suggest the possibility of a wide distribution of broadleaved forests with Pinus koraiensis at the edaphically suitable sites in the south of the Russian Far East. However, the area of this vegetation type is much smaller both in China and in the south of the Russian Far East (Petropavlovsky et al., 1985).

Human activity of the Dzhurzhen (Juchen, Jurchen) population between 500 and 700 cal BP has led to a decrease in the areas of forests due to clearing for agricultural lands. Since then the region has remained relatively densely populated, and regular fires have supported the development of vegetation without conifers (Nakamura and Krestov, 2005). In the south of the Russian Far East most fires have originated from human activities for the last 250 years (Sheingauz, 1996).

Using gap models, earlier studies predicted the change of forests under a warming climate in the region of Northeast China adjacent to 
the south of the Russian Far East. They predict drastic changes in the major forest types, where dominant species became extinct or were replaced within a relatively short period of time by species, which adapted better to new climate conditions. For example, the extinction of Pinus koraiensis within 80 years, followed by the complete dominance of Quercus mongolica was predicted in Pinus koraiensis-hardwood forests (Zhao et al., 1998; Hao et al., 2001).

The results of modelling the response of a forest ecosystem to warming of the climate, taking into account the spatial effects in northeastern China, show some recovery of Pinus koraiensis from the levels of low abundance due to cutting. But it is recovered to substantially lower abundance compared with the predicted current climatic scenario. Simulations with a warming climate scenario indicate that the abundance of Pinus koraiensis in north-eastern China will be $10 \%$ by $2290 \mathrm{AD}$ compared to the $44.5 \%$ under the current climate. At the same time, oak abundance in forests increases steadily from $20 \%$ at $1990 \mathrm{AD}$ to almost $40 \%$ by $2290 \mathrm{AD}$. Modelled proportions are $7 \%$ for maple, $3 \%$ for elm and basswood, and $2 \%$ for aspen by $2290 \mathrm{AD}$ (He et al., 2005).

According to one of the scenarios of climate change in the future (model CMIP5, phase five of the Coupled Model Inter-comparison Project), the global temperature averaged from 2041 to $2050 \mathrm{AD}$ is projected likely to exceed $2^{\circ} \mathrm{C}$ but unlikely to exceed $4^{\circ} \mathrm{C}$ above the global temperature averaged from 1850 to $1900 \mathrm{AD}$ (Stocker et al., 2013). Recent CMIP5 scenarios also predicted that not only surface air temperatures but also precipitation in north-east China between 2071 and $2100 \mathrm{AD}$ would be higher than those between 1986 and $2005 \mathrm{AD}$ (Xu and $\mathrm{Xu}, 2012$ ).

Based on the predicted averages of rainfall and temperature and a new model HadCM2 for 2030 , predictions were made on the future distributions of Pinus koraiensis. The result shows that the southern boundary of the potential distribution area of Pinus koraiensis would have a northward shift of $0.1^{\circ}$ to $0.6^{\circ}$ in latitude, and the northern boundary would have a northward shift from $0.3^{\circ}$ to $0.5^{\circ}$. Other parts of the distribution region remain roughly the same. The area of potential distribution of Pinus koraiensis would increase by $3.4 \%$ of the total distribution area compared with the area before climate change (Xu and Yan, 2001).

\section{CONCLUSIONS}

Palynological and chronostratigraphic data obtained in the course of our studies provided the grounds to determine the chronological timing of the spatial migration of Pinus koraiensis and to correlate it with the climate fluctuations explaining the changes of the geographical range of Pinus koraiensis in the south of the Russian Far East during MIS 5 (127 000-71 000 BP), MIS 3 (57 000 BP-28 000 cal BP), MIS 2 (28 000-11 $700 \mathrm{cal} \mathrm{BP})$, and MIS 1 (11 $700 \mathrm{cal}$ BP-to present). During MIS 5 and MIS 3, Pinus koraiensis was widely spread in the south of the Russian Far East. Under cold climate in MIS 2, Pinus koraiensis disappeared from the regional vegetation. At the transition from MIS 2 to MIS 1 the range of Pinus koraiensis expanded northwards. The species became the principal component of the vegetation in the south of the Russian Far East. The increase in its proportion in the vegetation in the Holocene coincided mostly with the periods of climate warming from 11700 to $11500 \mathrm{cal} \mathrm{BP}$, from 10100 to 9300 cal BP, from 8800 to 5300 cal BP, from 4700 to $3500 \mathrm{cal} \mathrm{BP}$, and from 2600 to $1800 \mathrm{cal}$ BP. In this case, the most diversified vegetation with Pinus koraiensis was typical of the Holocene optimum of the south of the Russian Far East from 8800 to $5300 \mathrm{cal} \mathrm{BP}$.

\section{ACKNOWLEDGMENTS}

The authors are grateful to Khikmatulla A. Arslanov (Saint Petersburg State University) for radiocarbon dating of samples, and Anatoly V. Lozhkin (Northeastern Integrated Scientific-Research Institute) for his scientific assistance. We are grateful to three anonymous reviewers for their constructive comments.

\section{REFERENCES}

Aizawa, M., Kim, Z.-S., Yoshimaru, H., 2012. Phylogeography of the Korean pine (Pinus koraiensis) in northeast Asia: inferences from organelle gene sequences. Journal of Plant Research 125, 713723, doi: 0.1007/s10265-012-0488-4.

Alekseyev, M.N., Golubeva, L.V., 1980. K stratigrafii i paleogeografii verhnego plejstocena Yuzhnogo Primor'ya. Byulleten' Komissii po izucheniyu chetvertichnogo perioda 50, 96-107.

Anderson, P.M., Belyanin, P.S., Belyanina, N.I., Lozhkin, A.V., 2017. Evolyuciya rastitel'nogo pokrova 
zapadnogo poberezh'ya Zaliva Petra Velikogo v Pozdnem Plejstocene-Golocene (summary: Evolution of the vegetation cover of Peter the Great Bay western coast in the Late Pleistocene-Holocene). Tihookeanskaya Geologiya 36(4), 206-215.

Bai, W.N., Liao, W.J., Zhang, D.Y., 2010. Nuclear and chloroplast DNA phylogeography reveal two refuge areas with asymmetrical gene flow in a temperate walnut tree from East Asia. New Phytologist 188, 892-901. https://doi.org/10.1111/ j.1469-8137.2010.03407.x

Bao, L., Ayijiamali, K., Bai, W.N., Chen, R.Z., Wang, T.M., Wang, H.F., Ge, J.P., 2015. Contributions of multiple refugia during the last Glacial period to current mainland populations of Korean pine (Pinus koraiensis). Scientific Reports 5. https://doi. org/10.1038/srep18608

Bazarova, V.B., Klimin, M.A., Mokhova, L.M., Orlova, L.A., 2008. New pollen records of Late Pleistocene and Holocene changes of environment and climate in the Lower Amur River basin, NE Eurasia. Quaternary International 179(1), 9-19. https://doi. org/10.1016/j.quaint.2007.08.015

Bassinot, F.C., Labeyrie, L.D., Vincent, E., Quidelleur, X., Shackleton, N.J., Lancelot, Y., 1994. The astronomical theory of climate and the age of the Brunes-Matuyama magnetic reversal. Earth and Planetary Science Letters 126, 91-108.

Belyanin, P.S., Belyanina, N.I., 2012. K evolyucii rastitel'nogo pokrova Prihankajskoj Vpadiny i ee gornogo obramleniya $\mathrm{v}$ pozdnem NeopleistoceneGolocene (po palinologicheskim dannym) (summary: On the Khanka depression vegetation evolution and its mountain framing in the Late Holocene-Neopleistocene (from palynological data). Tihookeanskaya Geologiya (31)2, 96-100.

Belyanin, P.S., Belyanina, N.I. 2018. Evolution of the Valley Ecosystems in the Lower Reaches of the Bikin River in the Late Pleistocene and the Holocene. Geography and Natural Resources (39)4, 365374. https://doi.org/10.1134/S1875372818040108

Belyanin, P.S., Belyanina, N.I., 2019. Changes of the Pinus koraiensis distribution in the south of the Russian Far East in the post Glacial time. Botanica Pacifica (8)1, 19-30. http://dx.doi.org/10.17581/bp.

Belyanin, P.S., Belyanina, N.I., 2020. Changes of vegetation in the eastern part of Khanka Plain (south of the Russian Far East) at the transition from the Late Pleistocene cryochron (MIS 2) to the Early Holocene. IOP Conf. Ser.: Earth Environ., https:// doi.org/10.1088/1755-1315/438/1/012003

Belyanin, P.S., Ivanov, V.V., Lesnov, S.V., Belyanina, N.I., Arslanov, Kh.A., Maksimov, F.E., 2018. Biostratigrafiya Verhneplejstocen-Golocenovyh dolinnyh otlozhenij Srednego Sihote-Alinya (na primere Bolotistogo Rossypnogo Polya v verhov'yah reki Hor) (summary: Biostratigraphy of the Upper Pleistocene-Holocene Valley deposits of the Middle Sikhote-Alin (Exemplified by the Bolotistoye Placer Field at the Khor River Head)). Vestnik
Severo-Vostochnogo Nauchnogo Tsentra FEB RAS $1,20-31$.

Belyanin, P.S., Anderson, P.M., Belyanina, N.I., Lozhkin, A.V., Arslanov, Kh.A., Maximov, F.E., Gornov, D.A. 2019. Evolyuciya rastitel'nogo pokrova zapadnogo poberezh'ya zaliva Petra Velikogo v Pozdnem Plejstocene-Golocene (summary: Vegetation Changes in the South of the Russian Far East in the Middle and Late Holocene). Izvestiya Rossiiskoi Akademii Nauk. Seriya Geograficheskaya 2, 69-84. https://doi.org/10.31857/S2587-55662019269-84

Bezrukova, E.V., Krivonogov, S.K., Abzayeva, A.A., Vershinin, K.E., Letunova, P.P., Orlova, L.A., Takahara, H., Mieshi, N., Nakamura, T., Krapivina, S.M., Kavamuro, K. 2005. Landshafty i klimat Pribajkal'ya v Pozdnelednikov'e i Golocene po rezul'tatam kompleksnyh issledovanij torfyanikov (summary: Environments and climate of the Prebaikalian region in the Late Glacial and Holocene based on interdisciplinary studies of peatlands). Geologiya i geofizika 46(1), 21-33.

Bezrukova, E.V., Letunova, P.P., Kulagina, N.V., Sharova, O.G. 2013. Rekonstrukciya prirodnoj sredy i landshaftov priol'hon'ya $\mathrm{v}$ golocene na osnove datirovannyh zapisej iz ozernyh otlozhenij (summary: Environment and landscape's reconstruction of the Priolkhon Region based on the data of lacustrine sediments). Evraziya v Kajnozoe. Stratigrafiya, Paleoekologiya, Kul'tury 2, 19-25.

Birks, H.J.B., 1986. Late-Quaternary biotic changes in terrestrial and lacustrine environments, with particular reference to north-west Europe: 3-65. In: Berglund, B.E. (ed.), Handbook of Holocene Palaeoecology and Palaeohydrology, Wiley, Chichester.

Borisov, B.A., 2009. Obshchaya stratigraficheskaya shkala kvartera. Opornye razrezy Neoplejstocena (summary: General stratigraphie chart of the Quarternary. Neopleistocenic reference sections of the European Part of Russia). Fundamental'nye problemy kvartera: itogi izucheniya i osnovnye napravleniya dal'nejshih issledovanij: materialy VI Vserossijskogo soveshchaniya po izucheniyu chetvertichnogo perioda, 84-88.

Bronk Ramsey, C., 2017. Methods for summarizing radiocarbon datasets. Radiocarbon 59(2), 18091833. https://doi.org/10.1017/RDC.2017.108

Chlachula, J., Lynsha, V.A., Kolaczek, P., Tarasenko, V.N., 2015. Neolithic and Aeneolithic Environments in the Central Primor'ye Region (the Bol'shaya Ussurka Valley), the Russian Far East. Quaternary International 370, 127-144. http:// dx.doi.org/10.1016/j.quaint.2014.12.065

Campbell, I.D. 1994. Pollen preservation: experimental wet-dry cycles in saline and desalinated sediments. Palynology (18), 5-10.

Cosford, J., Qing, H., Lin, Y., Eglington, B., Mattey, D., Chen, Y.G., Zhang, M., Cheng, H., 2010. The East Asian monsoon during MIS 2 expressed in a speleothem delta O-18 record from Jintanwan Cave, Hunan, China. Quaternary Research, 73(3), 541549. https://doi.org/10.1016/j.yqres.2010.01.003 
Critchfield, W.B., Little, E.L.Jr., 1966. Geographic Distribution of the Pines of the World, U.S. Department of Agriculture, Miscellaneous Publication 991, Washington.

Danko, L.V., Bezrukova, E.V., Orlova, L.A., 2009. Rekonstrukciya razvitiya geosistem Primorskogo Hrebta vo vtoroj polovine Golocena (summary: Reconstruction of the development of geosystems of the Primorsky Range in the second half of the Holocene). Geografiya i prirodnye resursy 3, 48-55.

Dobson, M., Kawamura, Y., 1998. Origin of the Japanese land mammal fauna: allocation of extant species to historically based categories. Quaternary Research 37, 385-395.

Drozdov, O.A., Vasiliev, V.A., Kobysheva, N.V., 1989. Klimatologiya (Climatology). Gidrometeoizdat, Leningrad.

Elsik, W.C., 1971. Microbiological degradation of sporopollenin. In: Brooks, J., Grant, P.R., Muir, M., Van Gijzel, P., and Shaw, G. (Eds), Sporopollenin. New York, Academic Press, pp. 480-511.

Formozov, A.N., 1976. Zveri, pticy i ih vzaimosvyazi so sredoj obitaniya. Nauka, Moskva.

Golubeva, L.V., Karaulova, L.P., 1983. Rastitel'nost' i klimatostratigrafiya Plejstocena i Golocena yuga Dal'nego Vostoka, Trudy GIN, 366, 141.

Grimm, E., 2004. Tilia software 2.0.2. Springfield: Illinois State Museum Research and Collection Center.

Grishin, S.Yu., 1995. The boreal forests of northeastern Eurasia. Vegetatio 121, 11-21.

Hao, Z., Dai, L., He, H.S., Mladenoff, D.J., Shao, G., 2001. Potential response of major tree species to climate warming in Chingbai Mountain. Chinese Journal of Applied Ecology 12, 653-658.

Harrison, S.P., Yu, C., Takahara, H., Prentice, I.C. 2001. Palaeovegetation: diversity of temperate plants in East Asia. Nature 413, 129-130. https:// doi.org/10.1038/35093166

Havinga, A.J., 1971. An experimental investigation into the decay of pollen and spores in various soil types. In: Brooks, J., Grant, P.R., Muir, M., Van Gijzel, P., and Shaw, G. (Eds), Sporopollenin. New York, Academic Press, pp.446-479.

He, H.S., Hao Z.Q., Mladenoff, D.J., Shao G.F., Hu, Y.M., Chang, Y. 2005. Simulating forest ecosystem response to climate warming incorporating spatial effects in north-eastern China. Journal of Biogeography 32, 2043-2056. https://doi.org/10.1111/ j.1365-2699.2005.01353.x

Hutchins, H.E., Hutchins, S.A., Liu, B., 1996. The role of birds and mammals in Korean pine (Pinus koraiensis) regeneration dynamics. Oecologia 107, 120-130. https://doi.org/10.1007/BF00582242

Igarashi, Y.A., 1993. History of environmental change in Hokkaido from the viewpoint of palynological research. Biodiversity and Ecology in the Northernmost Japan. Hokkaido Univ Press, Sapporo.

Ivanov, A.V., Shashenok, D.S., 2018. Sosna kedrovaya korejskaya Pinus koraiensis Siebold \& Zucc. v podpologovyh lesnyh kul'turah yuzhnoj chasti Dal'nego Vostoka (summary: Korean pine Pinus koraiensis Siebold \& Zucc. in under-canopy forest crops of the southern part of Far East). Sibirskij lesnoj zhurnal 6, 80-90.

Iverson, L.R., Schwartz, M.W., Prasad, A.M., 2004. How fast and far might tree species migrate in the eastern United States due to climate change? Global Ecology and Biogeography 13, 209-219.

Kabanov, N.E., 1977. Hvojnye derev'ya i kustarniki Dal'nego Vostoka. Nauka, Moskva.

Khotinsky, N.A., 1977. Golocen Severnoj Evrazii. Opyt transkontinental'noj korellyacii etapov razvitiya rastitel'nosti i klimata. Nauka, Moskva.

Kolesnikov, B.P., 1954. Korejskij kedr na sovetskom Dal'nem Vostoke. Komarovskie chteniya 4, 23-67 (in Russian).

Kolesnikov, B.P., 1956. Kedrovye lesa Dal'nego Vostoka. Moskva, Leningrad AN SSSR.

Komarov, V.L., 1949. Izbrannye sochineniya. Flora Man'chzhurii. Moskva, Leningrad, Akademiya Nauk.

Kong, W.S., Lee, S.G., Park, H.N., Lee, Y.M., Oh, S.H., 2014. Time-spatial distribution of Pinus in the Korean Peninsula. Quaternary International 344, 43-52. https://doi.org/10.1016/j.quaint.2014.03.038

Korotky, A.M., 2002. Mestonahozhdeniya v Primor'e (sites of of Primor'ye). In: Anderson, P.M., Lozhkin, A.V. (ed.), Pozdnechetvertichnye rastitel'nost' i klimaty Sibiri i Rossijskogo Dal'nego Vostoka (Palinologicheskaya i Radiouglerodnaya Baza Dannyh) (Late Quaternary vegetation and climate of Siberia and the Russian Far East (Palynological and Radiocarbon Database)). Magadan, NESC FEB RAS, pp. 257-369. (in Russian).

Korotky, A.M., Karaulova, L.P., Troitskaya, T.S., 1980. Chetvertichnye otlozheniya Primor'ya. Stratigrafiya i paleogeografiya s dostavkoj po Rossii v punkty. Novosibirsk, Nauka.

Kremenetski, C.V., Liu, K., MacDonald, G.M., 1998. The Late Quaternary dynamics of pines in northern Asia. In: Richardson, D.M. (ed.), Ecology and Biogeography of Pinus. Cambridge University Press, Cambridge, pp. 95-106.

Krestov, P.V., 2003. Forest Vegetation of Easternmost Russia (Russian Far East). In: Kolbek, J., Srutek, M., Box, E. (Eds) Forest vegetation of Northeast Asia. Kluwer Academic Publishers, Dordrecht, pp. 93-180.

Krestov, P.V., Song, J.S., Nakamura, Y., Verkholat, V.P., 2006. A phytosociological survey of the deciduous temperate forests of mainland Northeast Asia. Phytocoenologia 36(1), 77-150. https://doi. org/10.1127/0340-269X/2006/0036-0077

Lanner, R.M., 1998. Seed Dispersal in Pinus. In: Richardson, D.M. (Ed.), Ecology and Biogeography of Pinus. Cambridge University Press, pp. 281-295.

Lang, G., 1994. Quartäre Vegetationsgeschichte Europa. - Gustav Fisher Verlag, Jena, Stuttgart, New York. 
Ledig, F.T., 1998. Genetic Variation in Pinus. In: Richardson, D.M. (Ed.), Ecology and Biogeography of Pinus. Cambridge University Press, pp. 251-280.

Li, C., Wu, Y.A., Hou, X., 2011. Holocene vegetation and climate in Northeast China revealed from Jingbo Lake sediment. Quaternary Internaional 229, 67-73.

Litvintseva, M.V., 1975. Morfologiya pyl'cy sibirskih i blizkih k nim vidov sosny. Avtoreferat dissertacii na soiskanie uchenoj stepeni kandidata biologicheskih nauk. Leningrad.

Mattes, H., 1985. The role of animals in cembra pine forest regeneration. Proceedings of 3rd IUFRO workshop. Ber Eidgenoss Anstall Forst Versuch 270, 195-205.

Miki, S., 1956. Remains of Pinus koraiensis S. et Z. and associated remains in Japan. Botanical Magazine Tokyo 69, 477-454.

Mikishin, Yu.A., Petrenko, T.I., Gvozdeva, I.G., Popov, A.N., 2008. Evolution of Landscapes in Khasansky District (Southwest Primorye) in Late Pleistocene - Holocene. Proceedings of International Symposium «Human Ecosystem Changes in the Northern Circum Japan Sea Area (NCJSA) in Late Pleistocene» Tokyo, pp. 82-94.

Mikishin, Yu.A, Petrenko, T.I., Gvozdeva, I.G., 2019. Pozdnyaya faza Atlanticheskogo perioda Golocena na yuge Primor'ya (summary: Late Phase of Atlantic period of the Holocene in Southern Primorye (Russian Far East)). Advances in current natural sciences 12, 96-107.

Miyaki, M., 1987. Seed dispersal of the Korean pine, Pinus koraiensis, by the red squirrel, Sciurus vulgaris. Ecology Research 2, 147-157.

Monoszon-Smolina, M.Kh., 1949. O morfologii pyl'cy nekotoryh vidov roda Pinus. Botanicheskij zhurnal 34(9), 352-390.

Nakamura, J., 1980. Diagnostic characters of pollen grains of Japan, Part I. Special Publications from the Osaka Museum of Natural History, 13.

Nakamura, Y., Krestov P.V., 2005. Coniferous forests of the temperate zone of Asia. In: Andersson F. (ed.), Coniferous forests. Ecosystems of the World 6, Elsevier, New York, London, Paris, pp. 63-220.

Ohshima, K., 1990. The history of straits around the Japanese islands in the Late-Quaternary. Quaternary Research 29, 193-208. https://doi.org/10.4116/ jaqua.29.193

Ohwi, J., 1965. Flora of Japan. Washington, Switsonian Inst., 1067 pp.

Omelko, A.M., Omelko, M.M., 2017. Osobennosti sozdaniya kedrovkoj (Nucifraga caryocatactes) zapasov kedrovyh oreshkov i pitaniya imi v zimnij period vo vtorichnyh shirokolistvennyh lesah s posadkami sosny korejskoj (summary: Creating caches of nuts by nutcracker (Nucifraga caryocatactes) and using them in winter time in secondary broadleaved forests with plantations of Korean pine (Pinus koraiensis Sieb. \& Zucc.). Amurskij zoologicheskij zhurnal IX(2), 102-111.
Pavlyutkin, B.I., Belyanina, N.I., 2002. Chetvertichnye otlozheniya Primor'ya: nekotorye itogi sistematizacii i dal'nejshie perspektivy izucheya (summary: Quaternary deposits of the Prymorye Region: some results of systematization and prospects for future studies). Tihookeanskaya geologiya 21(3), 80-93.

Pavlyutkin, B.I., Pushkar, V.S., Belyanina, N.I., Okovitaya, N.A., Lobanova, L.A., 1984. Golocenovye otlozheya bassejna r. Razdol'noj (yugo-zapadnoe Primor'e). Paleogeograficheskie rubezhi i metody ih izucheya. Vladivostok: DVNC AN SSSR.

Petropavlovsky, B.S., Chavtur, N.A., Dochevaya, N.V., 1985. Antropogennye izmeneya v lesah Primorskogo kraya. In: Dinamika rastitel'nosti yuga Dal'nego Vostoka. Dal'nauka, Vladivostok, pp. 44-51.

Pokrovskaya, I.M., 1950. Pyl'cevoj analiz. Gosgeolizdat, Moskva (in Russian).

POWO. 2019. Plants of the World Online. Facilitated by the Royal Botanic Gardens, Kew. Available from: http://www.plantsoftheworldonline.org. Accessed May 2021.

Qiu, Y.X., Fu, C.X., Comes, H.P., 2011. Plant molecular phylogeography in China and adjacent regions: tracing the genetic imprints of Quaternary climate and environmntal change in the world's most diverse temperate flora. Molecular Phylogenetics and Evolution 59, 225-244. https://doi. org/10.1016/j.ympev.2011.01.012

Razjigaeva, N.G., Ganzey, L.A., Mokhova, L.M., Makarova, T.R., Pachev, A.M., Kudryavtseva, E.P., Arslanov, Kh.A., Maksimov, F.E., Starikova, A.A., 2016. Razvitie landshaftov Shkotovskogo Plato Sihote-Alinya v Pozdnem Golocene (summary: Evolution of the environments on Skotovo Plateau, Sikhote-Alin, in the Late Holocene). Izvestiya Rossiiskoi Akademii Nauk, Seriya Geograficheskaya 3, 65-80. https://doi.org/10.15356/0373-24442016-3-65-80

Reimer, P.J., Austin, W.E.N, Bard, E., Bayliss, A., Blackwell, P.G., Bronk Ramsey, C., Butzin, M., Cheng, H., Edwards, R.L., Friedrich, M., Grootes, P.M., Guilderson, T.P., Hajdas, I., Heaton, T.J., Hogg, A.G,. Hughen, K.A., Kromer, B., Manning, S.W., Muscheler, R., Palmer, J.G., Pearson, C., Van Der Plicht, J., Reimer, R.W., Richards, D.A., Scott, E.M., Southon, J.R., Turney, C.S.M., Wacker, L., Adolphi, F., Büntgen, U., Capano, M., Fahrni, S.M., Fogtmann-Schulz, A., Friedrich, R., Köhler, P., Kudsk, S., Miyake, F., Olsen, J., Reinig, F., Sakamoto, M., Sookdeo, A., Talamo, S., 2020. The Intcal20 Northern Hemisphere Radiocarbon age calibration curve (0-55 cal kbp). Radiocarbon 62(4), 779-80. https://doi.org/10.1017/RDC.2020.41

Ren, G., Zhang, L., 1998. A preliminary mapped summary of Holocene pollen data for Northeast China. Quaternary Science Reviews 17, 669-688. https:// doi.org/10.1016/S0277-3791(98)00017-1

Sheingauz, A.S., 1996. The role of fires in forest cover, structure, and dynamics in the Russian Far East. In: Goldammer, J.G., Furyaev, V.V. (ed.) Fires in 
ecosystems of boreal Eurasia, Kluwer Academic Publishers, Dordrecht, pp. 186-190.

Solovyev, K.P., 1958. Kedrovo-shirokolistvennye lesa Dal'nego Vostoka i hozyajstvo v h. Habarovskoe kzhnoe izdatel'stvo, Habarovsk (in Russian).

Song, U., Park, J., Song, M., 2012. Pollen morphology of Pinus (Pinaceae) in northeast China, Forest Science and Technology 8(4), 179-186. https://doi.org/ 10.1080/21580103.2012.704973

Stebich, M., Rehfeld, K., Schlütz, F., Tarasov, P.E., Liu, J., Mingram, J., 2015. Holocene vegetation and climate dynamic of NE China based on the pollen record from Sihailongwan Maar Lake. Quaternary Science Reviews 124, 275-289. https://doi. org/10.1016/j.quascirev.2015.07.021

Stocker, T.F., Dahe, Q., Plattner, G.K., 2013. Climate Change 2013: The Physical Science Basis. Working Group I Contribution to the Fifth Assessment Report of the Intergovernmental Panel on Climate Change. Summary for Policymakers (IPCC, 2013).

Tsukada, M., 1984. A vegetation map of the Japanese Archipelago approximately 20000 years BP. Japanese Journal of Ecology 34, 203-208.

Urusov, V.M., 1999. Sosny i sosnyaki Dal'nego Vostoka. Vladivostok, Tihookeanskij institut geografii DVO RAN.

Velichko, A.A., 2012. Evolyucionnaya geografiya: problemy i puti resheya. Moskva, GEOS.

Walker, M.J.C., Berkelhammer, M., Björck, S., Cwynar, L.C., Fisher, D.A., Long, A.J., Lowe, J.J., Newnham, R.M., Rasmussen, S.O., Weiss, H., 2012. Formal subdivision of the Holocene Series/
Epoch: a discussion paper by a Working Group of INTIMATE (Integration of ice-core marine and terrestrial records) and the Subcommission on Quaternary Stratigraphy (International Commission on Stratigraphy). Journal of Quaternary Science 27, 649-659. https://doi.org/10.1002/jqs.2565

Wanner, H., Beer, J., Butikofer, J., Crowley, T.J., Cubasch, U., Fluckiger, J., Goosse, H., Grosjean, M., Joos, F., Kaplan, J.O., Kuttel, M., Muller, S.A., Prentice, I.C., Solomina, O., Stocker, T.F., Tarasov, P., Wagner, M., Widmann, M., 2008. Mid- to Late Holocene climate change: an overview. Quaternary Science Reviews 27, 1791-1828. https://doi. org/10.1016/j.quascirev.2008.06.013

Zhang, J., Zhou, Y., Zhou, G., Xiao, C., 2014. Composition and Structure of Pinus koraiensis Mixed Forest Respond to Spatial Climatic Changes. PLoS ONE 9(5), 1-10.

Zhao, S., Yan, X., Yang, S., Tao, D., Dai, L., 1998. Simulating responses of northeastern China forests to potential climate change. Journal of Forestry Research 9, 166-172. https://doi.org/10.1007/ BF02910063

Xu, C.-H., Xu, Y., 2012. The Projection of Temperature and Precipitation over China under RCP Scenarios using a CMIP5 Multi-Model Ensemble, Atmospheric and Oceanic Science Letters 5(6), 527-533. https://doi.org/10.1080/16742834.2012.11447042

$\mathrm{Xu}$, D., Yan, H.A., 2001. A study of the impacts of climate change on the geographic distribution of Pinus koraiensis in China. Environmental International 27(2-3), 201-205. https://doi.org/10.1016/ s0160-4120(01)00083-6 